\title{
Sensing via intestinal sweet taste pathways
}

\author{
Richard L. Young*
}

Discipline of Medicine, School of Medicine, University of Adelaide, Adelaide, SA, Australia

\section{Edited by:}

L. Ashley Blackshaw, University of Adelaide, Australia

Reviewed by:

Helen Raybould, University of

California at Davis, USA

G. J. Dockray, University of Liverpool, UK

\section{${ }^{*}$ Correspondence:}

Richard L. Young, Nerve-Gut Research Laboratory, Hanson Institute, Frome Road, Adelaide, SA 5000, Australia. e-mail: richard.young@adelaide.edu.au.

\section{INTRODUCTION}

The ability to sense the chemical composition of ingested material and respond appropriately is critical to individual survival. The gastrointestinal (GI) tract possesses specific sensors throughout its length which are tuned to detect the wide array of luminal stimuli present, and in response, direct neural and humoral signals that control motility, digestion, and absorption. Knowledge of the primary chemosensory mechanisms used by the GI tract is limited, and this will need to be addressed since it is fundamental to being able to manipulate digestive physiology in patients with a spectrum of disorders involving the gut, including obesity, malnutrition, diabetes mellitus, and those with functional GI syndromes.

It is well established that exposure of the proximal small intestine to the products of carbohydrate digestion generates signals that powerfully influence motor and sensory function of the GI tract. This small intestinal feedback is critical to the regulation of gastric emptying, which is tightly controlled in health in the range $1-3 \mathrm{kcal} /$ min (Brener et al., 1983), and to the generation of GI symptoms and the secretion of peptide hormones that induce satiation or influence glycemic control. While a number of these responses are triggered via true humoral pathways upon interaction of nutrients with specialized gut epithelial cells, many result from paracrine activation of the intrinsic and extrinsic nerve pathways of the GI tract (see Cummings and Overduin, 2007; Raybould, 2010). There is strong functional evidence for vagus nerve pathways mediating chemosensory responses from the intestine. Early studies revealed that disruption of vagal pathways via subdiaphragmatic vagotomy or afferent denervation largely or completely blocked inhibition of

Abbreviations: 5-HT, 5-hydroxytryptamine (serotonin); ATP, adenosine 5'-triphosphate; cAMP, $3^{\prime}-5^{\prime}$-cyclic adenosine monophosphate; CCK, cholecystokinin; EC, enterochromaffin cells; GABA, $\gamma$-aminobutyric acid; GI, gastrointestinal; GIP, gastric inhibitory polypeptide (glucose-dependent insulinotropic peptide); GLP-1, glucagon-like peptide-1; GLP-2, glucagon-like peptide-2; GPCR, G-protein coupled receptor; $\mathrm{IP}_{3}$, inositol trisphosphate; PLC $\beta 2$, phospholipase $\mathrm{C} \beta 2$; PYY, peptide YY; T1Rx, type 1 taste receptor family $(\mathrm{T} 1 \mathrm{R} 2+\mathrm{T} 1 \mathrm{R} 3=$ sweet, T1R1 + T1R3 = uma$\mathrm{mi}$ ); T2R, type 2 taste receptor family (bitter); TRPM4, type- 4 melastatin transient receptor potential cation channel; TRPM5, type-5 melastatin transient receptor potential cation channel. gastric emptying, gastric acid secretion, and food intake in response to intestinal nutrient exposure in animals and humans (Wilkinson and Johnston, 1973; Roze et al., 1977; Raybould and Holzer, 1992; Schwartz et al., 1993). Over subsequent years, considerable progress has been made in understanding the activation and connectivity of vagus nerve pathways involved in nutrient reflexes, and their subsequent control of glycemia, food intake, and satiety (Raybould, 1991, 2010; Zittel et al., 1994; Lavin et al., 1996; Imeryuz et al., 1997; Broberger and Hokfelt, 2001; Blackshaw et al., 2007). It is now known that in the presence of intestinal nutrient, vagal afferent endings are activated by signals from epithelial cells and convey sensory information to the central nervous system for processing. In response to these signals, gastric vagal motor neurons mediate an "accommodation" response, involving relaxation of the proximal stomach (Azpiroz and Malagelada, 1987; Horowitz and Dent, 1991) together with suppression of antral contractions and the stimulation of tonic and phasic pyloric pressures (Figure 1). The net effect of these actions is to slow gastric emptying to a rate matched to the absorptive capacity of the small intestine (Raybould, 1998). The sensory arm of this reflex is critically dependent on the length and region of small intestine exposed to nutrient and prior nutrient exposure, while the motor events powerfully influence glycemic control (Lin et al., 1989; Horowitz et al., 2002; Little et al., 2006).

Vagal sensory innervation of the intestine arises from afferent neurons with cell bodies in the nodose and jugular ganglia, with endings concentrated in the upper GI tract. Anterograde nerve tracing studies have shown that vagal afferent nerves terminate within the parenchyma of mucosal villi in close contact with the basal lamina, but not with the epithelial surface (Berthoud et al., 1995). This anatomy largely precludes a direct action of luminal nutrient on vagal afferents and suggests that specialized epithelial cells within the intestinal mucosa serve as primary sense cells for nutrients. Specialized intestinal epithelial cells represent less than $1 \%$ of the intestinal cell population but collectively from the largest endocrine organ of the body. These regionally distributed mucosal cells possess receptors and transduction machinery to sense luminal stimuli, and in turn, collectively release over 20 different gut 


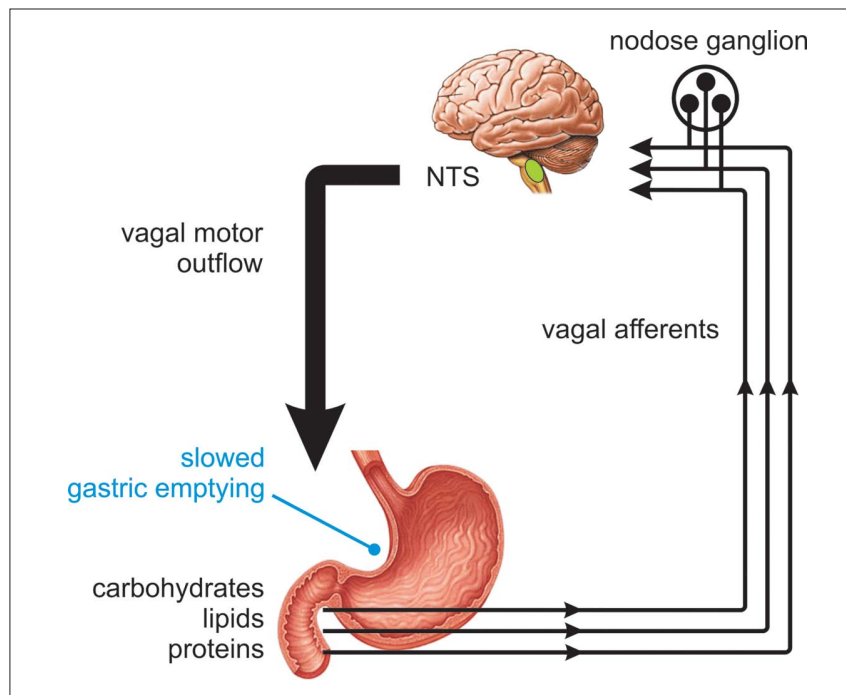

FIGURE 1 | Nutrient feedback from the proximal small intestine. Nutrients present in the proximal small intestine trigger vagal reflex control of gut motor function, slowing gastric emptying to a rate matched to the absorptive capacity of the small intestine.

peptides or bioactive molecules throughout the GI tract (see Rindi et al., 2004; Cummings and Overduin, 2007). As a consequence, the intestine is likely to sense nutrients at multiple sites and recruit diverse and cascading sensing strategies. In support of a paracrine action involving the enteroendocrine cells, vagal afferent nerves are known to express receptors for a number of key hormones released by gut epithelial cells, including those released in response to luminal nutrients such as carbohydrates (Kakei et al., 2002; Raybould et al., 2003; Nakagawa et al., 2004; Vahl et al., 2007; Bucinskaite et al., 2009). However, although paracrine mediators and vagal pathways involved in intestinal nutrient signaling are beginning to be revealed, the molecular identity of transduction mechanisms involved in nutrient detection in the GI tract remain poorly defined. In contrast, the identities of molecules involved in detecting sweetness in the tongue have been elucidated much more thoroughly (Nelson et al., 2001; Zhao et al., 2003).

Taste receptor cells in the oral cavity form the frontline of sensory detection of the GI tract and provide immediate and critical input to direct innate affective behaviors (to high caloric food sources) or aversive behaviors (to noxious substances). Taste buds comprise a heterogeneous group of 50-150 taste receptor cells, which are located throughout the tongue and soft palate. Taste receptor cells are classified on an ultrastructural basis into four cell classes - type I (dark) cells are candidate taste cells for salty taste and likely to have a support role akin to glial cells (Lawton et al., 2000; Vandenbeuch et al., 2008), type II (light) cells frequently possess apical microvilli and are individually receptive to either sweet, bitter, or umami (amino acid) stimuli (Yang et al., 2000; Clapp et al., 2004; DeFazio et al., 2006). Type III (presynaptic) cells are candidate sour taste cells and the only taste cell to form synapses with gustatory nerves (Huang et al., 2008; Kataoka et al., 2008), while type IV (basal) cells are presumed to be progenitor cells (Stone et al., 2002). Differences in the expression of taste receptors and transduction molecules in type
II and III cells have also been reported between circumvallate and fungiform papillae, suggesting that these cells display differential sensitivities according to their physical location (Kim et al., 2003; Shigemura et al., 2008).

The attractive taste modalities, sweet and umami, are detected by a small family of class-C, G-protein coupled receptors (GPCR) T1R1, T1R2, and T1R3 - which are related to metabotropic glutamate, extracellular calcium-sensing, and type B $\gamma$-aminobutyric-acid receptors. Subsets of T1R have been shown to heterodimerize to form a umami receptor (T1R1 + T1R3), responsive to the $\mathrm{L}$-amino acids glutamate and aspartate, or to heterodimerize to form a broadly tuned sweet taste receptor $(\mathrm{T} 1 \mathrm{R} 2+\mathrm{T} 1 \mathrm{R} 3)$ responsive to sugars, D-amino acids, sweet proteins and sweeteners. It is also proposed that T1R2 or T1R3 may homodimerize in some circumstances to form low-efficiency sweet taste receptors (Hoon et al., 1999; Nelson et al., 2001, 2002; Li et al., 2002; Damak et al., 2003; Zhao et al., 2003; Delay et al., 2006). T1R receptor dimers have been shown to be expressed in individual taste receptor cells, equipping them to detect a single taste modality (Adler et al., 2000; Nelson et al., 2001; Yoshida et al., 2009). Indeed, persuasive evidence now exists of a labeled-line model of taste discrimination which occurs at the level of the taste receptor cell (Chandrashekar et al., 2006; Yarmolinsky et al., 2009).

$\mathrm{T} 1 \mathrm{R}$ receptors possess a characteristic large extracellular $\mathrm{N}$-terminus domain linked to a seven-transmembrane C-terminal domain by a short cysteine-rich domain. Bitter taste, in contrast, is mediated by a diverse family of around 30 class-C GPCR - the T2R which possess short $\mathrm{N}$-terminus domains and which are frequently co-expressed in bitter responsive taste cells (Chandrashekar et al., 2000; Lindemann, 2001). A common intracellular signal transduction pathway is activated by T1R or T2R stimuli in individual taste receptor cells, involving activation of $\mathrm{G} \alpha-, \mathrm{G} \beta_{3^{-}}$, and $\mathrm{G} \gamma_{13}$-subunits of the taste-specific G-protein, gustducin, followed by a signal transduction cascade involving phospholipase C 32 (PLC $\beta 2)$ and inositol trisphosphate $\left(\mathrm{IP}_{3}\right)$. This cascade results in the release of intracellular $\mathrm{Ca}^{2+}$ and gating of the taste-specific cation channel TRPM5 (Wong et al., 1996; Perez et al., 2002; Chandrashekar et al., 2006; Clapp et al., 2008). It is also well described that $\alpha$-gustducin reduces intracellular levels of cAMP through activation of phosphodiesterases (Clapp et al., 2008). Depolarization then occurs, and mediators are released from taste receptor cells to activate gustatory nerves in a paracrine manner; norepinephrine, glutamate, acetylcholine, cholecystokinin (CCK), vasoactive intestinal peptide, neuropeptide $\mathrm{Y}$, adenosine $5^{\prime}$-triphosphate (ATP), serotonin (5-HT), and the incretin hormone glucagon-like peptide-1 (GLP-1) have been identified as taste receptor cell mediators thus far (Nagahama and Kurihara, 1985; Nagai et al., 1998; Finger et al., 2005; Shen et al., 2005; Zhao et al., 2005; Roper, 2007; Martin et al., 2009).

\section{PARALLELS BETWEEN TONGUE AND SMALL INTESTINAL TASTE MECHANISMS}

There is unequivocal evidence that the presence of carbohydrate in the proximal small intestine slows gastric emptying in a response that is nutrient-specific, and not secondary to an increase in osmolality detected by intestinal osmoreceptors (Lin et al., 1989). The notion that taste mechanisms exist throughout the GI tract is drawn from similarities between specialized intestinal epithelial cells and 
lingual taste cells. Both cell types are polarized, possess apical microvilli that are exposed to the chemical environment of the lumen and are equipped to release neuromediators (Figure 2). Evidence from studies focused on carbohydrate absorption has also added support, with functional studies underpinning the actions of a specific glucose sensor on the luminal surface (Dyer et al., 2003; Margolskee et al., 2007).

A key advance in understanding sensory systems of the GI tract was the work of Höfer et al. (1996) and Höfer and Drenckhahn (1998), who identified mRNA and protein expression of $\alpha$-gustducin in brush cells of the gastric cardia, duodenum, and pancreatic duct of rats. This finding built on earlier work of this group in which GI brush cells were shown to express high levels of nitric oxide synthase (Kugler et al., 1994) and raised the possibility of nitric oxide as the first putative mediator of this transduction pathway. Subsequent studies in a number of rodent intestinal cell lines and tissues revealed that sweet taste receptors T1R2 and T1R3, along with their signal transduction partner $\alpha$-gustducin, were expressed in the small intestine at mRNA and protein level (Dyer et al., 2005; Margolskee et al., 2007). Our work extended this key finding to reveal that immunolabeling for $\alpha$-gustducin was expressed throughout the GI tract with peak expression in epithelial cells of the mid-jejunum (Sutherland et al., 2007a), where carbohydrateinduced reflexes are likely to be initiated (Lin et al., 1989). This study also explored the phenotype of intestinal epithelial cells in mice that expressed $\alpha$-gustducin (Figure 3); the majority of taste cells in the mid-jejunum were identified as brush cells (57\%) with the remainder representing distinct populations of 5-HT-containing enterochromaffin (EC) cells (27\%) or GLP-1-containing L-cells (15\%; Sutherland et al., 2007a).
These data support the hypothesis that lingual taste pathways are conserved throughout the alimentary tract and employed in primary intestinal chemosensation. However, they also indicate that the majority of intestinal taste cells in mice employ mediators other than GLP-1 or 5-HT in intestinal signaling. A further key finding was that, like lingual taste receptor cells, multiple components of the sweet taste GPCR pathway were expressed in individual intestinal taste cells. This evidence was provided at protein level by Mace et al. (2007), who showed co-localization of T1R2 and T1R3 in jejunal epithelial cells in rats using immunolabeling. Quantitative molecular approaches also revealed that T1R, T2R, and $\alpha$-gustducin were co-expressed within TRPM5-expressing duodenal epithelial cells in mice, demonstrating that a complete sweet taste transduction cascade could operate within these cells (Bezencon et al., 2007).

Expression of sweet taste molecules in the human GI tract was first shown by Rozengurt et al. (2006), who demonstrated immunolabeling for $\alpha$-gustducin in colonic epithelial L-cells that also expressed GLP-1 and peptide YY (PYY). Follow-up molecular studies from our group and others have since revealed expression of T1R2, T1R3, $\alpha$-gustducin, and TRPM5 throughout the human GI tract, noting prominent expression in the proximal small intestine (Bezencon et al., 2007; Young et al., 2009). One-third of taste cells (expressing $\alpha$-gustducin) in the duodenum have been shown to be L-cells, while a smaller proportion were found to be K-cells expressing glucose-dependent insulinotropic peptide (GIP) or incretin cells that expressed both GLP-1 and GIP (K/L-cells; Theodorakis et al., 2006; Jang et al., 2007). This seminal study also revealed expression of sweet taste receptors and signal transduction partners in individual duodenal L-cells.

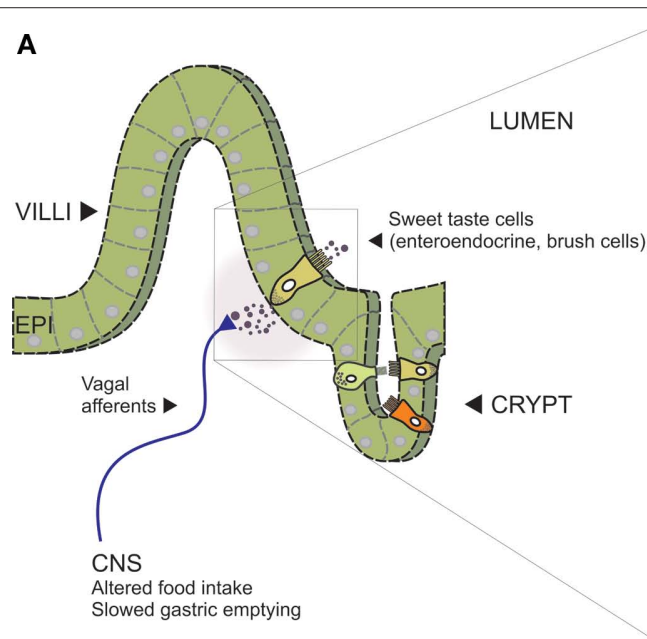

B

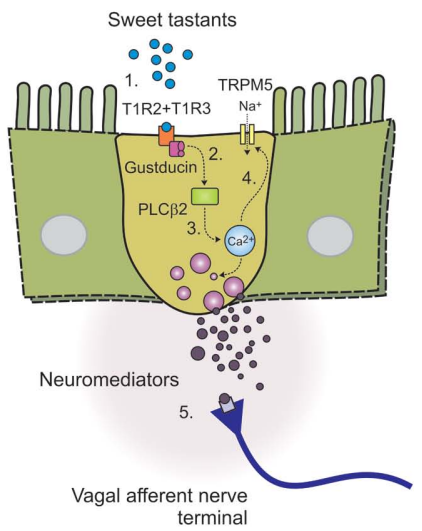

FIGURE 2 | Model of intestinal sensing by sweet taste cells and mucosal vagal afferents (adapted, with permission, from Bertrand, 2009). (A) Intestinal wall showing villus-crypt and location of sweet taste cells. Different sweet taste cells are shown within the epithelial layer (EPI, alternate colors) indicating the range of intestinal enteroendocrine and brush cells identified with sweet taste machinery. Vagal afferent nerve terminals are shown adjacent the basolateral membrane where they can be activated in response to paracrine signaling (neuromediators), triggering nutrient reflexes that alter behavior (food intake) and slow gastric emptying. (B) Expanded schematic of boxed area in (A), showing key components of the intestinal sweet taste signaling pathway proposed to operate in an enteroendocrine sweet taste cell; (1) Heterodimeric sweet taste receptors comprising the GPCRT1R2 andT1R3 detect a wide range of sweet tastants in the intestinal lumen, (2) Upon GPCR binding, the taste-specific G-protein Gustducin is activated, liberating $G \alpha$ and G $\beta 3$ and G $\gamma 13$-subunits which are thought to activate PLC $\beta 2$, (3) leading to the release of intracellular calcium from $\mathrm{IP}_{3}$-sensitive stores. G $\alpha$-gustducin may also reduce intracellular levels of cAMP via activation of phosphodiesterases (not shown), (4) Rising intracellular calcium can then gate the taste-specific cation channel TRPM5, leading to $\mathrm{Na}^{+}$influx, membrane depolarization, neuromediator release, and (5) nerve terminal activation. 

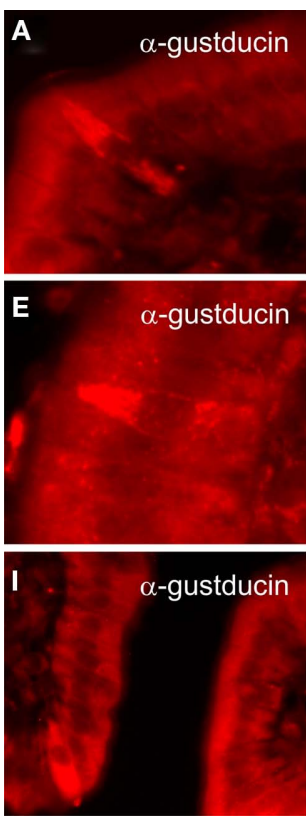
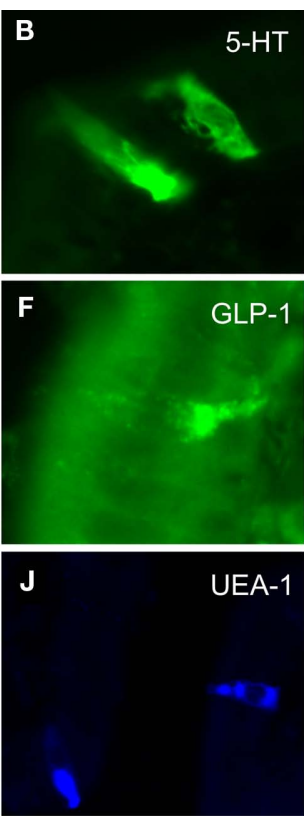
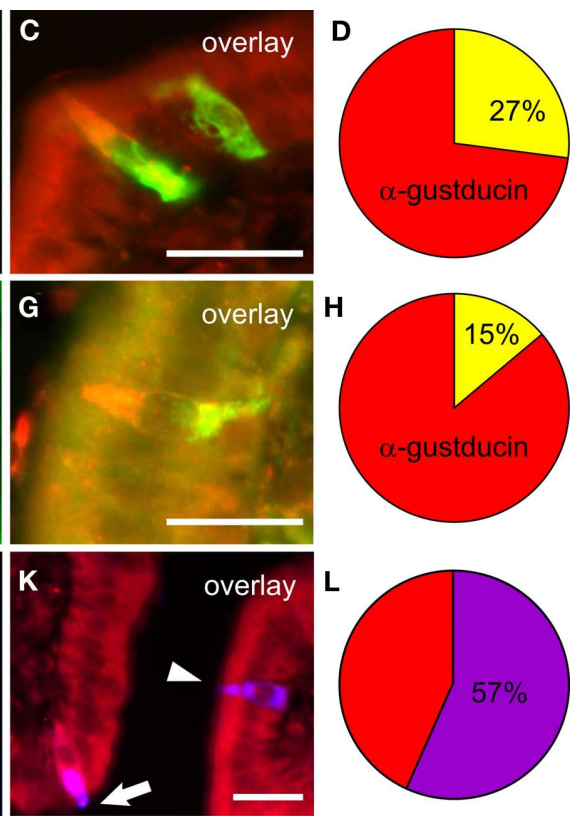

FIGURE 3 | Co-expression of $\alpha$-gustducin within mucosal cell populations in mouse jejunum (from Sutherland et al., 2007a). Immunolabeling for $\alpha$-gustducin "taste" cells in mouse jejunal mucosa (red fluorescence, A,E,I) was present in cells colabeled for 5-HT (green, B), GLP-1 (green, $\mathbf{F}$ ), or brush cell-like labeled by the plant lectin Ulex europaeus agglutinin-1 (UEA-1; blue, J). Composite images (yellow, C,G; purple, K) depict localization within the same cells. The majority of $\alpha$-gustducin cells in mouse jejunum were brush cell-like ( $57 \pm 4 \%$ of all $\alpha$-gustducin cells, L), while smaller proportions were 5 -HT producing enterochromaffin cells $(27 \pm 2 \%$, D) or GLP-1 producing L-cells $(15 \pm 2 \%, \mathbf{H})$. Scale bar $=50 \mu \mathrm{M}$.
Much awaited functional evidence of intestinal sweet taste mechanisms was provided simultaneously in cell lines and in knockout mice deficient in $\alpha$-gustducin. Firstly, mouse endocrine cells of the GLUTag line showed markedly increased GLP-1 and GIP secretion upon exposure to the sweetener sucralose, which was subsequently blocked by the sweet taste inhibitor gurmarin (Margolskee et al., 2007). Similar results were obtained for sucralose stimulated GLP-1 release in the human L-cell line NCI-H716, which was blocked by either RNA interference targeting of $\alpha$-gustducin or the human sweet taste antagonist lactisole (Jang et al., 2007). Second, knockout mice lacking $\alpha$-gustducin displayed a major a deficit in glucosestimulated GLP-1 release, along with a corresponding delay in reaching peak circulating insulin levels (Jang et al., 2007). Together, these results strongly linked the function of sweet taste molecules to intestinal incretin hormone release.

It is now well established that chronic changes in luminal glucose exposure modify GI response to glucoses; for example, chronic increases in dietary carbohydrate reduce satiety satiation and accelerate gastric emptying in response to subsequent carbohydrate intake in healthy humans (Horowitz et al., 1996), while starvation is associated with delayed gastric emptying of glucose (Corvilain et al., 1995). Correspondingly, intestinal sweet taste molecules undergo dynamic regulation of expression in response to luminal or systemic glucose, which appears to be an essential feature of this system. Mace et al. (2007) first showed that exposure of rat jejunal membrane fractions to high concentrations of glucose or sucralose led to rapid trafficking of T1R2, T1R3, and $\alpha$-gustducin protein away from the brush border. Our group subsequently identified transcriptional control of T1R2 by intestinal glucose in anesthetized mice. We showed that transcript levels of T1R2 were markedly reduced in glucose-perfused jejunal loops, in the absence of changes in blood glucose level or levels of other taste molecule transcripts (Young et al., 2009). We also reported that the copy numbers of T1R2, T1R3, $\alpha$-gustducin, and TRPM5 transcripts in human duodenal biopsies were inversely correlated with blood glucose levels at the time of endoscopy (Young et al., 2009). Taken together, these findings indicate that levels of sweet taste molecule transcripts are modulated in the intestine by both luminal and metabolic factors - a feature that may reflect their signaling of acute postprandial nutrients and chronic dietary intake patterns. Importantly, these data highlight the importance of considering prevailing and historic exposure of intestinal sweet taste receptors to their environment in order to accurately gage their respective mRNA or protein levels.

There is also much interest in recent news that sweet taste molecules are widely distributed in other glucose sensing structures. $\mathrm{T} 1 \mathrm{R}$ and taste G-proteins have now been identified in nutrientsensitive forebrain structures in mice, where they register circulating glucose levels in a metabolism-independent manner and display similar transcriptional control mechanisms to sweet taste molecules of the intestine (Ren et al., 2009). Mouse pancreatic $\beta$-islet cells have also recently been shown to express T1R2, T1R3, TRPM5, and $\alpha$-gustducin, and to release insulin in a T1R-cAMP dependent manner (Reimann et al., 2008; Nakagawa et al., 2009; Brixel et al., 2010). While the functional significance of these findings is yet to be fully evaluated they indicate that sugar sensing occurs in these tissues via mechanisms that are both dependent and independent of metabolism. Such strategies may be critical in 
fine-tuning systems responses for glucose homeostasis, and support the notion of multiple sensing strategies for carbohydrates (discussed further below).

\section{TASTE MECHANISMS IN SPECIALIZED INTESTINAL EPITHELIAL CELLS}

Understanding the phenotype of intestinal epithelial cells that bear sweet taste receptors is an important focus of a number of research groups, and candidate cells have been identified. Here, evidence of specific endocrine and brush cells involved in intestinal sweet taste transduction is reviewed, with reference to expression in cell culture, rodents and humans (Table 1).

\section{L-CELLS}

Much research effort has been focused on L-cells due to their ability to detect digestion products of carbohydrates, fats, and proteins and respond by secreting the incretin hormone GLP-1. L-cells are distributed throughout the GI tract, with greatest density in the distal intestine (ileum, colon); yet not insignificant numbers are present in the proximal small intestine in most species (Bryant et al., 1983; Eissele et al., 1992). These cells use alternative post-translational processing of proglucagon to produce the bioactive peptides GLP-1, GLP-2, and oxyntomodulin, although most attention has focused on the actions of GLP-1 (Holst, 2007). GLP-1 is known to be released rapidly in proportion to caloric load and the length of small intestine exposed to carbohydrate, and acts to increase satiation, stimulate insulin release, suppress glucagon secretion and slow gastric emptying (Schirra and Göke, 2005; Horowitz and Nauck, 2006; Little et al., 2006). In addition, complex carbohydrates that reach the distal intestine may be fermented to short chain fatty acids, which can also interact with L-cells via other nutrient sensors (for review, see Reimann, 2010). Effects of GLP-1 on slowing of gastric emptying are mediated largely via a vagal reflex pathway; GLP-1 receptors have been localized on abdominal vagal afferents, on nodose ganglion neurons and in brainstem neurons (notably within the dorsal vagal complex; (Drucker and Asa, 1988; Goke et al., 1995; Imeryuz et al., 1997; Merchenthaler et al., 1999; Kakei et al., 2002; Nakagawa et al., 2004). While GLP-1 has also been shown to excite vagal afferents directly, the gastroinhibition achieved may occur in part via a central site of action on vagal motor neurons (Imeryuz et al., 1997; Kakei et al., 2002; Nagell et al., 2006; Nakade et al., 2006; Bucinskaite et al., 2009; Holmes et al., 2009; Ruttimann et al., 2009). However, the relative importance of a central site of action of endogenous GLP-1 is uncertain, due to the rapid degradation of GLP-1 that occurs within minutes at the site of peripheral release and within the circulation and liver by the ubiquitous enzyme dipeptidyl peptidase-IV (Deacon et al., 1996; Holst, 2007). The functional importance of GLP-1 in mediating reflex actions of intestinal carbohydrate on gastric emptying rate is now well established - genetic variation around the GLP-1 allele strongly correlates with changes in gastric emptying rate in mice strains (Kumar et al., 2008) while the GLP-1 antagonist exendin (9-39) accelerates gastric emptying in both rodents and humans (Imeryuz et al., 1997; Schirra et al., 2009; Deane et al., 2010).

L-cell lines of mouse and human origin were amongst the first shown to express transcripts for T1R2, T1R3, and $\alpha$-gustducin and to release GLP-1 via sweet taste receptor mechanisms (Reimann and Gribble, 2002; Dyer et al., 2005; Jang et al., 2007; Margolskee et al., 2007). Immunolabeling studies in mouse and human intestine subsequently revealed populations of L-cells equipped with $\alpha$-gustducin that ranged from $15 \%$ (mouse mid-jejunum) up to $90 \%$ of all L-cells (human duodenum; Rozengurt et al., 2006; Jang et al., 2007; Sutherland et al., 2007b). Half of all small intestinal L-cells in weaned piglets were also recently shown to be immunolabeled for T1R (Moran et al., 2010b). Much awaited functional evidence of intestinal taste signaling was provided by Jang et al. (2007), who showed that mice deficient in expression of $\alpha$-gustducin

Table 1 | Sweet taste molecules identified in small intestinal cell populations.

\begin{tabular}{|c|c|c|c|c|}
\hline Cell type & $\begin{array}{l}\text { Major transmitters } \\
\text { minor transmitter }\end{array}$ & Cell culture & Rodents & Human \\
\hline \multicolumn{5}{|c|}{ Enteroendocrine } \\
\hline \multirow[t]{2}{*}{ L-cell } & GLP-1 & T1R2, T1R3, GD & T1R2, T1R3, GD & T1R2, T1R3 \\
\hline & GLP-2, PYY, oxyntomodulin & & & GD, TRPM5 \\
\hline K-cell & GIP & & T1R2, T1R3, GD & GD \\
\hline L/K-cell & GLP-1, GIP & & & GD \\
\hline \multirow[t]{2}{*}{ EC cell } & $5-\mathrm{HT}$ & & & \\
\hline & $\begin{array}{l}\text { chromogranin-A, ATP, melatonin, } \\
\text { GABA, uroguanylin, dynorphin }\end{array}$ & T1R3 & GD & \\
\hline I-cell & CCK & T1R2, T1R3, GD & & \\
\hline \multirow[t]{2}{*}{ Brush cell } & Nitric oxide* & & & \\
\hline & $\begin{array}{l}\beta \text {-endorphin, Met-enkephalin, } \\
\text { uroguanylin }\end{array}$ & & $\begin{array}{l}\text { T1R1, T1R3 } \\
\text { GD, TRPM5 }\end{array}$ & \\
\hline Enterocyte & None known & - & - & - \\
\hline
\end{tabular}

*Gastrointestinal brush cells in rats express neuronal nitric oxide synthase (Höfer et al., 1996), which is not expressed in mouse intestinal bush cells (Sutherland et al., 2007b). Cell culture includes mucosal cells cultured from rodent and human origin. GD, $\alpha-g u s t d u c i n ;-$, no expression; blank cell, not determined. Bold text indicates major transmitters for each cell type, unbolded text indicates minor transmitters. 
possessed impaired glucose-stimulated GLP-1 secretion, the first such evidence linking sweet taste signaling to incretin hormone responses. However, despite these multiple lines of evidence a number of studies have provided contrary views. Examination of highly purified L-cell populations from transgenic mice revealed only marginal levels of transcript for sweet taste molecules and an inability of sucralose to stimulate GLP-1 release from primary small intestinal cell cultures (Reimann et al., 2008). Whether these findings reflect the small proportion of L-cells known to express $\alpha$-gustducin in rodents (Sutherland et al., 2007b), the prevailing cell isolation conditions or sensitivity of transcript detection in these studies is unclear. In addition, while a significant $\alpha$-gustducin/L-cell population is reported to exist in human duodenum (Jang et al., 2007), our own studies indicate that primarily separate populations of cells express GLP-1 or $\alpha$-gustducin in duodenal biopsies from healthy humans (Young et al., 2010). Whether this difference is due to the use of postmortem tissue in the studies by Jang et al. (2007) compared to our own studies using fresh tissue sources is unclear. It should also be noted that in all studies to date, less than half of all $\alpha$-gustducin cells in the proximal small intestine of animals and humans co-express GLP-1, suggesting other mediators are likely to be important in signaling sweet and/or other taste modalities. Finally, while sweet taste receptor mechanism have been strongly linked to L-cell responses, the presence of other glucose sensing pathways are known in these cells, including electrogenic glucose transporters and metabolism-dependent mechanisms (Tolhurst et al., 2009; Reimann, 2010); these are discussed in turn below. The exact roles of sweet taste receptors in L-cells are not established, and key experiments are awaited to resolve their contribution to glucose-stimulated release of GLP-1 in animals and humans.

\section{K-CELLS}

Glucose-dependent insulinotropic peptide-secreting K-cells are located within the proximal small intestine, and are responsive to digestion products of both carbohydrates and fat, as well as certain amino acids (Baggio and Drucker, 2007). GIP is rapidly released postprandially in proportion to calorific load (Pilichiewicz et al., 2007), and acts to stimulate insulin release and to promote lipid storage in adipocytes, the latter an emerging role that may link overnutrition to obesity (Yip et al., 1998; Baggio and Drucker, 2007; Kim et al., 2007). In contrast to GLP-1, exogenous GIP does not alter the rate of gastric emptying in response to carbohydrates, and correspondingly, vagal afferents in rodents lack receptors and functional responses to GIP (Nishizawa et al., 1996; Meier et al., 2004; Nakagawa et al., 2004).

As limited cell lines are available to study GIP secretion, transgenic mice have recently been developed which express fluorescent K-cells (Parker et al., 2009). Highly purified K-cells from these mice express only marginal levels of transcript for T1R2, T1R3, and $\alpha$-gustducin, and high levels of transcript for GPCR linked to fat detection. Like findings for L-cells, it is not clear if these low transcript levels reflect the small population of K-cells shown to colabel for $\alpha$-gustducin in rodents (30\%; Fujita et al., 2009), or for T1R in weaned piglets (50\%; Moran et al., 2010b). A major study in humans also revealed that less than half of all K-cells in duodenum expressed $\alpha$-gustducin, while all incretin cells that expressed both GLP-1 and GIP (K/L-cells; Theodorakis et al., 2006) also expressed $\alpha$-gustducin (Jang et al., 2007). Functional release of GIP has been shown to occur by a sweet taste pathway in the mouse GLUTag cell line, while mice that lack $\alpha$-gustducin display abnormal GIP release following glucose gavage (Jang et al., 2007; Margolskee et al., 2007). Together these observations support a functional role of sweet taste receptors in intestinal GIP release, as for GLP-1. However GIP release is known to be critically dependent on sugar absorption by the intestinal sodium-glucose co-transporter 1 (SGLT-1) and is inhibited in the presence of the competitive SGLT-1 inhibitor phloridzin (Sykes et al., 1980; Fushiki et al., 1992). Rapidly and slowly digestible carbohydrates are also known to differ considerably in their ability to stimulate GIP secretion indicating that an absorptive pathway is the major route for triggering GIP release in humans (Wachters-Hagedoorn et al., 2006). Indeed GIP may, itself, act to stimulate expression of SGLT-1, based on in vitro evidence in mice (Singh et al., 2008). Ligands that interact at the sweet taste receptor (gurmarin, stevioside) however do not appear to influence in vivo GIP release in rats (Fushiki et al., 1992). Taken together, while sweet taste signaling pathways may be functional in K-cells key experiments are awaited to resolve their contribution to GIP release in animals and humans.

\section{ENTEROCHROMAFFIN CELLS}

Serotonin (5-HT) secreting EC cells are a prominent enteroendocrine cell type in the GI tract and an important target for transducing a wide array of chemical and mechanical cues (for reviews, see Grundy, 2006, 2008; Blackshaw et al., 2007; Raybould, 2010). EC cells are distributed throughout the GI tract and exert paracrine effects via 5-HT release and activation of 5-HT receptors present on intrinsic and extrinsic nerve endings within the submucosa; circulating 5-HT levels are kept low due to specific uptake into platelets. A number of other bioactive compounds have also been identified in EC cell populations, including chromogranin-A, melatonin, ATP, GABA, uroguanylin, and dynorphin although less is know of their actions in the intestine (see Bertrand and Bertrand, 2010). In contrast to other enteroendocrine cells in the GI tract, functional responses of native EC cell to luminal stimuli are less well characterized. It is known that carbohydrates can trigger 5-HT release from EC cell lines and from purified human small intestinal EC cells (Kim et al., 2001; Kidd et al., 2008). Correspondingly, 5- $\mathrm{HT}_{3}$ receptors are expressed on small intestinal vagal afferents in rodents and $5-\mathrm{HT}_{3}$ receptor antagonists block vagal afferent activation, and suppression of food intake, as well as attenuate slowing of gastric emptying in rodents in response to intestinal carbohydrates (Zhu et al., 2001; Glatzle et al., 2002; Raybould et al., 2003; Savastano et al., 2005; Wu et al., 2005). Effects of 5- $\mathrm{HT}_{3}$ receptor antagonists on carbohydrate-induced slowing of gastric emptying have not been reported in humans, and although a single study has described an attenuation of solid meal emptying in healthy subjects by a $5-\mathrm{HT}_{3}$ receptor antagonist (Akkermans et al., 1988), most indicate no effect (Stacher et al., 1990, 1991; Netzer et al., 2002). Together these data suggest that the involvement of $5-\mathrm{HT}_{3}$ receptors in gastric emptying reflexes is likely to be species-specific, but with a limited role in humans.

The presence of sweet taste molecules was first described in mouse intestinal EC cells by our group, where a quarter of midjejunal EC cells demonstrated immunolabeling for $\alpha$-gustducin (Sutherland et al., 2007b). A small population of intestinal EC 
cells in weaned piglets was also recently shown to be immunolabeled for T1R (Moran et al., 2010b). Based on studies in TRPM5-transgenic mice, however, it appears that if taste signaling is functional in EC cells, it is likely to operate independent of TRPM5 (Bezencon et al., 2008; Kokrashvili et al., 2009). Indeed, TRPM4 has been proposed as an alternative taste transduction partner based on lingual studies performed in TRPM5-deficient mice (Ohkuri et al., 2009). Transcripts for T1R3 and T2R have also been identified in purified human small intestinal EC cells, and despite the apparent absence of T1R2 transcript, these cells released 5-HT in response to stimulation with the sweetener sucralose (Kidd et al., 2008). Sucralose stimulation also led to phosphorylation of extracellular signal-related kinase in these EC cells, itself a cardinal feature of sweet taste receptor activation (Ozeck et al., 2004; Jang et al., 2007). Human EC cells, however, also expressed the glucose transporter SGLT-1, and 5-HT responses were abolished in the presence of phloridzin (Kidd et al., 2008), raising the prospect that SGLT-1-dependent release mechanisms may operate in EC cells, as has been proposed for L- and K-cells.

\section{I-CELLS}

Cholecystokinin-secreting I-cells are located largely within the proximal small intestine and are more responsive to digestion products of fats and proteins, than to carbohydrates (Rehfeld, 1978; Cummings and Overduin, 2007). However, it is well established that CCK is released by intraduodenal glucose infusions in humans, and like GIP release, is independent of the length of small intestine exposure (Liddle et al., 1985; Little et al., 2006). While considerable evidence is gathering for roles of bitter taste receptors and other nutrient receptors in intestinal CCK release, evidence from mouse enteroendocrine STC-1 cells (which secrete CCK) shows expression of transcripts for T1R2, T1R3, and $\alpha$-gustducin (Wu et al., 2002; Dyer et al., 2005; Rozengurt and Sternini, 2007), indicating that sweet taste signaling may be involved in glucose-induced CCK release. However, STC-1 cells are poorly differentiated and multipotential and it remains to be established if the potential for sweet taste signaling in this cell line translates to CCK release mechanisms in native I-cells.

\section{BRUSH CELLS (TUFT OR CAVEOLATED CELLS)}

Brush cells are sparse within the epithelium of the respiratory and GI tracts of animals, and are rare in humans (Reid et al., 2005). These cells possess a distinct pear shape and apical microvilli similar to lingual taste cells, but unlike enteroendocrine cells, do not contain secretory granules or transmitter vesicles. The possibility of brush cells participating in nutrient signaling was first recognized by Höfer and Drenckhahn $(1996,1998)$ and Höfer et al. (1996), who identified solitary brush cells immunopositive for the taste $\mathrm{G}$-protein $\alpha$-gustducin in the gastric cardia, duodenum and pancreatic duct of the rat, based on cell morphology and immunolabeling for the cytoskeletal markers villin and cytokeratin-18. These brush cells were also immunopositive for neuronal nitric oxide synthase ( $\mathrm{nNOS}$ ) suggesting a possible role for nitric oxide (NO) in taste signaling from brush cells in rats. In our studies, we used binding of the plant lectin Ulex europaeus agglutinin-1 (UEA-1) as a species-specific marker for the glycocalyx of brush cells in mice (Gebert et al., 2000). We revealed that over half of solitary taste cells in the mouse small intestine (immunopositive for $\alpha$-gustducin) bound UEA-1 (Sutherland et al., 2007b). However, despite the use of multiple antisera against nNOS, all brush taste cells in mice were immunonegative for nNOS (Sutherland et al., 2007b). This finding reveals that intestinal brush cells are likely to contribute significantly to taste signaling in mice via an as yet unidentified, non-nitrergic mediator. To this end, TRPM5-expressing intestinal cells in transgenic mice were recently shown to resemble brush cells morphologically and immunologically, and to express high levels of the opioids $\beta$-endorphin and Met-enkephalin in the apical portion, as well as uroguanylin (Kokrashvili et al., 2009). However, in the same study these cells were also shown to be unresponsive to glucose or a sweetener ex vivo, indicating an apparent lack of sweet taste signaling mechanisms. This is an intriguing finding given that a high proportion of the same cell population identified by another group expressed T1R1, T1R3, and $\alpha$-gustducin but not T1R2 (Bezencon et al., 2007), and may point toward a signal role of this cell type for umami stimuli. Alternatively, this finding may indicate that TRPM5-independent signaling of sweet taste may operate in subsets of intestinal brush cells (or in endocrine cells) as occurs in different lingual taste receptor cells (Ohkuri et al., 2009). Other signal candidates for brush cells include the gaseous mediators carbon monoxide or hydrogen sulfide (Miller et al., 1998; Bezencon et al., 2008; Linden et al., 2008).

Due to the unmet requirement of a definitive marker of bush cells in humans little data exist for comparative taste molecule expression in human GI brush cells, despite their rarity. In our own recent study GI epithelial cells immunopositive for $\alpha$-gustducin in humans displayed similar morphology to rodent brush cells (Sutherland et al., 2008), however other data in humans has primarily focused on taste molecule expression in endocrine cells. Ultrastructural studies have however revealed that as in rodents, GI brush cells in humans may be extensively innervated at their basal membrane (Morroni et al., 2007; Bezencon et al., 2008), providing further support of a receptive role for this cell type.

\section{PURINERGIC CELLS}

A role for purinergic signaling in lingual taste transduction is now well established. Early studies revealed the presence of ionotropic $\mathrm{P} 2 \mathrm{X} 2$ and $\mathrm{P} 2 \mathrm{X} 3$ receptors in gustatory nerve endings innervating fungiform and vallate taste buds (Bo et al., 1999) and the expression of $\mathrm{P} 2 \mathrm{Y}$ receptors coupled to calcium mobilization in taste (Kim et al., 2000; Baryshnikov et al., 2003; Kataoka et al., 2004). P2Y receptors also have been shown to direct paracrine signaling events with 5-HT between taste receptor cell types (Huang et al., 2009). The development of P2X2/P2X3 double knockout mice has provided key information on functional roles of these receptors. These mice display major deficits or complete loss of behavioral and lingual afferent responses to all taste stimuli (Finger et al., 2005). The function of P2X receptors in intestinal nutrient sensing has not been directly investigated, although P2X receptor antagonists have been shown to partially block the motor responses of the small intestine to luminal nutrient in guinea pigs (Gwynne and Bornstein, 2007). Recent developments in lingual 
taste research have also led to the identification of the ATP-release hemichannels pannexin- 1 and connexin-43 in taste receptor cells responsive to sweet, bitter, and umami stimuli (Romanov et al., 2007; Huang et al., 2009). Moreover, functional evidence of a role for pannexin-1 channels/ATP in lingual taste signaling have been very recently revealed in type II taste receptor cells (Murata et al., 2010); it is likely that markers of pannexin-1 will have future application in probing the phenotype of intestinal taste cells in animals and humans.

\section{OTHER MECHANISMS OF PERIPHERAL GLUCOSE DETECTION $\mathrm{K}_{\text {ATP }}$ CHANNEL-DEPENDENT GLUCOSE SENSING}

ATP-sensitive $K_{\text {ATP }}$ channels are archetypal glucose sensors which act as metabolism-dependent ion channels in a number of tissues, most notably in pancreatic $\beta$-cells. These channels close in the face of increasing intracellular levels of ATP (and falling MgADP) that accompany glucokinase-dependent glucose metabolism. Due to subsequently reduced background $\mathrm{K}^{+}$ion flux, small inward currents then facilitate membrane depolarization, which trigger action potentials, $\mathrm{Ca}^{2+}$ entry via voltage-gated $\mathrm{Ca}^{2+}$ channels and insulin secretion (Rorsman, 1997). It is well established that $\mathrm{K}_{\text {АTP }}$ channels (as well as glucokinase) are expressed in both cell lines and native intestinal L-cells and K-cells in mice and humans (Reimann et al., 2005; Theodorakis et al., 2006; Nielsen et al., 2007; Parker et al., 2009). Despite this, in vivo evidence for a dominant role of $\mathrm{K}_{\text {ATP }}$ channels in intestinal glucose sensing is currently lacking. Furthermore, it is well established that elevated blood glucose levels per se do not trigger incretin hormone secretion, nor do sulfonylureas, which effectively inhibit $\mathrm{K}_{\mathrm{ATP}}$ channels and are used therapeutically to stimulate insulin secretion in human type 2 diabetes (El-Ouaghlidi et al., 2007).

\section{ELECTROGENIC TRANSPORT (FACILITATIVE GLUCOSE TRANSPORTERS)}

Observations that incretin hormone release was triggered by nonmetabolizable substrates of intestinal SGLT-1 in vitro and blocked by its selective inhibitor phloridzin led the concept that SGLT-1 acted as a glucose transceptor, capable of transport and signaling glucose (Sykes et al., 1980; Ritzel et al., 1997; Gribble et al., 2003). SGLT-1 transports glucose across the apical brush border membrane of intestinal epithelial cells with strict stoichiometry to $\mathrm{Na}^{+}(1: 2)$ and was shown to generate a net inward current in GLUTag cells sufficient to trigger membrane depolarization and GLP-1 secretion (Gribble et al., 2003). It was noted, however, that inward currents generated in these in vitro studies were very small, and that facilitative background current(s) would be required to trigger electrical activity (Tolhurst et al., 2009), reducing the prospect of SGLT-1 acting as the primary intestinal glucose sensor. However, the first in vivo evidence of glucose-stimulated incretin hormone release that was blocked by phloridzin was recently revealed in mice (Moriya et al., 2009). This finding indicates that SGLT-1 transport may well be a critical determinant of incretin hormone release, at least in this species. SGLT-3, a closely related family member to SGLT-1 that bound with low-affinity but did not transport substrates has also been proposed to serve as an intestinal glucose sensor (Diez-Sampedro et al., 2003; Freeman et al., 2006). However, other studies have indicated that SGLT-3 is not expressed on the intestinal cell surface, and therefore unlikely to be involved in primary glucose responses (Dyer et al., 2007).
A number of animal studies have established that intestinal expression of SGLT-1 is increased in the presence of a broad array of sweet ligands, including artificial sweeteners. This process is now known to occur independent of metabolism and via a sweet taste receptor pathway (Shirazi-Beechey et al., 1991; Dyer et al., 2003; Moran et al., 2010a; Stearns et al., 2010). Critical to this understanding was evidence provided by Margolskee et al. (2007), who showed that intestinal SGLT-1 was not upregulated in response to dietary glucose or sucralose in mice deficient in $\alpha$-gustducin or T1R3. Along with sweet taste receptors, vagal reflex pathways also appear to play an important role in the control of SGLT-1. Evidence in animals subject to selective vagal afferent ablation has shown that the expected increase in SGLT-1 protein is lost in response to acute and chronic intestinal glucose exposure, and to circadian pattern at anticipated feeding times (Bates et al., 1998; Stearns et al., 2008, 2010). The efferent limb of this vagal reflex is currently unknown, however both cholinergic and opioid receptors may be involved (McFadden et al., 1984; Bastidas et al., 1989). Such a neural reflex may explain the observation that glucose exposure of isolated regions of the GI tract in rats leads to increased SGLT-1 in non-exposed regions (Stearns et al., 2010). It is also possible that a humoral reflex pathway is triggered by intestinal glucose to modulate distant SGLT-1 expression, for example, GIP release has been proposed as a mechanism linking intestinal sweet taste receptor activation to SGLT-1 regulation in mice (Margolskee et al., 2007; Singh et al., 2008). 5-HT also appears to be involved in this signaling in rats, as the $5-\mathrm{HT}_{3}$ receptor antagonist ondansetron reduced accumulation of SGLT-1 in response to glucose (Stearns et al., 2010). Together, these observations in animals strongly support the presence of a sweet taste receptor pathway that coordinates intestinal glucose transport capacity in accord with luminal stimuli, and which acts via reflex vagal pathways.

This mechanism, however, may not extend to humans. A study recently performed by our group to address this possibility in healthy subjects failed to identify any effect of sucralose to enhance acute absorption of intraduodenal infused glucose (Ma et al., 2010). However, the concentration of infused glucose in this study may have saturated available glucose transporters, and therein, masked a possible synergy between sucralose and glucose. It has also yet to be shown whether prolonged exposure to dietary sweeteners can increase small intestinal glucose absorption in humans as it does in mice (Margolskee et al., 2007), or if responses in humans may be sweetener specific.

The facilitative glucose transporter GLUT2 (which normally transports monosaccharides across the basolateral membrane into circulation) is also regulated by sweet taste receptors in rats. Mace et al. $(2007,2008)$ have established that intracellular trafficking of GLUT2 and insertion into the apical brush border membrane of intestinal epithelial cells in rats occurs via a sweet taste receptor mechanism. These data imply that, at least in rats, sweet taste receptors link the presence of sweeteners or high levels of glucose in the intestine to increased glucose transport capacity via SGLT-1 and GLUT2. However this mechanism may be species-specific as apical GLUT2 is not detected in intestinal epithelial cells from pigs following carbohydrate supplemented diets (Moran et al., 2010b). Moreover, the rare incidence of glucose-galactose malabsorption in infants (which results from mutations in the SGLT-1 gene; Turk et al., 1991), argues against the presence of a mechanism in humans to translocate GLUT2 to the brush border membrane to otherwise facilitate monosaccharide absorption. 


\section{INTESTINAL SWEET TASTE MOLECULES IN DIABETES}

Animal models of diabetes and humans with diabetes consistently show altered sensitivity of vagal feedback from the proximal intestine in response to carbohydrate. In particular, patients with diabetes exhibit exaggerated upper GI motility reflexes in response to nutrient infusion in the small intestine (Rayner et al., 2002) and up to $50 \%$ with longstanding diabetes experience delayed gastric emptying and associated symptoms, such as nausea, abdominal discomfort, and disturbed glycemic control following a meal (Horowitz et al., 2002). Current management of these patients is often suboptimal, due to a lack of understanding of the underlying pathophysiology. It is know that while the prevalence of delayed gastric emptying is high in diabetic patients with autonomic neuropathy, its presence only weakly correlates with disordered cardiovascular autonomic function (Horowitz et al., 1991), suggesting other pathogenic factors are likely to be more important. Correspondingly, an understanding of the regulation of intestinal sweet taste molecules in diabetic patients is likely to be important in assessing their altered sensitivity of nutrient feedback.

Our study was the first to compare intestinal levels of sweet taste molecules in patients with well controlled type 2 diabetes to those without diabetes. This revealed no significant difference in absolute copy number of these transcripts in duodenal biopsies of fasted patients between groups (Young et al., 2009). However, transcript levels of all sweet taste molecules were inversely correlated with blood glucose levels at the time of endoscopy, indicating control of expression by metabolic status. Since there is functional evidence that sweet taste molecules are linked to GLP-1 release (Jang et al., 2007), a maladaptive consequence of downregulated sweet taste receptors in patients with poorly controlled type 2 diabetes could be to impair GLP-1 secretion. This would be consistent with the observation that such patients have a diminished GLP-1 response to a meal when compared with healthy subjects (Holst and Gromada, 2004). This setting may also limit any potential benefits of therapies designed to enhance endogenous GLP-1 release, particularly in comparison to the therapeutic use of GLP-1 mimetics (such as exenatide or liraglutide).

\section{FOOD FOR THOUGHT}

Despite evidence supporting an intestinal role of artificial sweeteners in cell systems and a number of animal studies, some studies now suggest that sweeteners may be functionally inert in the intestine. Studies performed by our group, and others in rodents and humans have revealed that acute intragastric administration of a range of sweeteners does not lead to elevated circulating GLP-1 or GIP, or to the slowing of gastric emptying (Gregersen et al., 2004; Fujita et al., 2009; Little et al., 2009; Ma et al., 2009). In this respect sucralose is known to bind lingual sweet taste receptors with different affinity from sucrose, and shows differences in central activation in functional brain imaging (Nie et al., 2005; Frank et al., 2008). Moreover, mice

\section{REFERENCES}

Adler, E., Hoon, M. A., Mueller, K. L., Chandrashekar, J., Ryba, N. J., and Zuker, C. S. (2000). A novel family of mammalian taste receptors. Cell 100, 693-702.

Akkermans, L. M., Vos, A., Hoekstra, A., Roelofs, J. M., and Horowitz, M.
(1988). Effect of ICS 205-930 (a specific 5-HT3 receptor antagonist) on gastric emptying of a solid meal in normal subjects. Gut 29, 1249-1252.

Azpiroz, F., and Malagelada, J. R. (1987). Gastric tone measured by an electronic barostat in health and postsurgical gastroparesis. Gastroenterology92,934-943.

that lack T1R3 or TRPM5 show a complete loss of taste preference to sucralose, but retain residual responses to sucrose suggesting the presence of T1R3 or TRPM5 independent sweet signaling (Damak et al., 2003, 2006). It is, however, currently unknown whether chronic exposure of the intestine to sweeteners exerts intestinal effects; such an effect, for example, may explain the enhanced GLP-1 release in response to a high fat diet seen following chronic exposure of mice to the non-digestible sugar oligofructose (Cani et al., 2006).

It is also of interest that mouse colonic epithelial cell cultures exposed to sucralose trigger GLP-1 release in a manner that is additive with glucose, suggestive of sweet taste synergism (Reimann et al., 2008). A recent human study has added further support in revealing that ingestion of diet soda (sweetened with sucralose and acesulfame-K) prior to oral glucose load modestly increased GLP-1 release in healthy young volunteers (Brown et al., 2009). These authors concluded that while sweeteners did not release GLP-1 per se, they synergized with glucose to increase GLP-1 release (Brown et al., 2009). It is also well established that multiple allosteric binding sites exist for T1R2 and T1R3 and that lingual sweet taste synergism readily occurs between combinations of sweeteners known to occupy both orthosteric and allosteric binding sites (Schiffman et al., 1995; Xu et al., 2004; Morini et al., 2005; Zhang et al., 2010). Whether taste synergism translates to in vivo function of intestinal sweet taste receptors is not established, and the potential for interaction between sugars (which bind the orthosteric site) and sweeteners that bind allosteric sites on the intestinal T1R2 receptor is yet to be explored.

\section{CONCLUSION}

Based on their relevant distribution and emerging intestinal functions there is much evidence to support sweet taste receptors as the luminal-facing GPCR tuned to carbohydrates and sweeteners in the GI tract. However, key experiments are still needed to determine the signaling mode of sweet taste cells in the human intestine and the contribution of their signals to the triggering of gut hormone release and vagal-mediated nutrient reflexes. In addition, the emerging role of sweet taste receptors in the regulation of intestinal sugar transport capacity remains to be clarified. Despite these caveats, the recent and rapid identification of GPCR involved in lingual and intestinal nutrient detection offers real potential to manipulate digestive physiology for therapeutic gain in patients with disorders of gut motility or sensation, glycemic control, or food intake.

\section{ACKNOWLEDGMENTS}

Thanks to A/Prof Paul Bertrand for his kind provision of image resources for this manuscript and to A/Prof Christopher Rayner for helpful comments on the manuscript. Financial support from the Diabetes Australia Research Trust and NHMRC (Australia) project grant \# 627127.

Baggio, L. L., and Drucker, D. J. (2007) Biology of incretins: GLP-1 and GIP. Gastroenterology 132, 2131-2157.

Baryshnikov, S. G., Rogachevskaja, O. A., and Kolesnikov, S. S. (2003). Calcium signaling mediated by $\mathrm{P} 2 \mathrm{Y}$ receptors in mouse taste cells. J. Neurophysiol. 90, 3283-3294.
Bastidas, J. A., Yeo, C. J., Schmieg, R. E. Jr. and Zinner, M. J. (1989). Endogenous opiates in the mediation of early meal-induced jejunal absorption of water and electrolytes. Am. J. Surg. 157, 27-32.

Bates, S. L., Sharkey, K. A., and Meddings, J. B. (1998). Vagal involvement in die- 
tary regulation of nutrient transport. Am. J. Physiol. 274, G552-G560.

Berthoud, H. R., Kressel, M., Raybould, H. E., and Neuhuber, W. L. (1995). Vagal sensors in the rat duodenal mucosa: distribution and structure as revealed by in vivo DiI-tracing. Anat. Embryol. 191, 203-212.

Bertrand, P. P. (2009). The cornucopia of intestinal chemosensory transduction. Front. Neurosci. 3, 1-9. doi: 10.3389/ neuro.21.003.2009

Bertrand, P. P., and Bertrand, R. L. (2010). Serotonin release and uptake in the gastrointestinal tract. Auton. Neurosci. 153, 47-57.

Bezencon, C., Furholz, A., Raymond, F., Mansourian, R., Metairon, S.,LeCoutre, J., and Damak, S. (2008). Murine intestinal cells expressing Trpm 5 are mostly brush cells and express markers of neuronal and inflammatory cells. J. Comp. Neurol. 509, 514-525.

Bezencon, C., le Coutre, J., and Damak, S. (2007). Taste-signaling proteins are coexpressed in solitary intestinal epithelial cells. Chem. Senses 32, 41-49.

Blackshaw, L. A., Brookes, S. J., Grundy, D., and Schemann, M. (2007). Sensory transmission in the gastrointestinal tract. Neurogastroenterol. Motil. 19, $1-19$.

Bo, X., Alavi, A., Xiang, Z., Oglesby, I., Ford, A., and Burnstock, G. (1999). Localization of ATP-gated P2X2 and $\mathrm{P} 2 \mathrm{X} 3$ receptor immunoreactive nerves in rat taste buds. Neuroreport $10,1107-1111$.

Brener, W., Hendrix, T. R., and McHugh, P. R. (1983). Regulation of the gastric emptying of glucose. Gastroenterology 85, 76-82.

Brixel, L. R., Monteilh-Zoller, M. K., Ingenbrandt, C. S., Fleig, A., Penner, R., Enklaar, T., Zabel, B. U., and Prawitt, D. (2010). TRPM5 regulates glucosestimulated insulin secretion. Pflugers Arch. 460, 69-76.

Broberger, C., and Hokfelt, T. (2001). Hypothalamic and vagal neuropeptide circuitries regulating food intake. Physiol. Behav. 74, 669-682.

Brown, R. J., Walter, M., and Rother, K. I. (2009). Ingestion of diet soda before a glucose load augments glucagon-like peptide-1 secretion. Diabetes Care 32, 2184-2186.

Bryant, M. G., Bloom, S. R., Polak, J. M., Hobbs, S., Domschke, W., Domschke, S., Mitznegg, P., Ruppin, H., and Demling, L. (1983). Measurement of gut hormonal peptides in biopsies from human stomach and proximal small intestine. Gut 24, 114-119.

Bucinskaite, V., Tolessa, T., Pedersen, J., Rydqvist, B., Zerihun, L., Holst, J. J., and Hellstrom, P.M. (2009). Receptormediated activation of gastric vagal afferents by glucagon-like peptide-1 in the rat. Neurogastroenterol. Motil. 21, 978-e978.

Cani, P. D., Knauf, C., Iglesias, M. A., Drucker, D. J., Delzenne, N. M., and Burcelin, R. (2006). Improvement of glucose tolerance and hepatic insulin sensitivity by oligofructose requires a functional glucagon-like peptide 1 receptor. Diabetes 55, 1484-1490.

Chandrashekar, J., Hoon, M. A., Ryba, N. J., and Zuker, C. S. (2006). The receptors and cells for mammalian taste. Nature 444, 288-294.

Chandrashekar, J., Mueller, K. L., Hoon, M. A., Adler, E., Feng, L., Guo, W., Zuker, C. S., and Ryba, N. J. (2000). T2Rs function as bitter taste receptors. Cell 100, 703-711.

Clapp, T. R., Trubey, K. R., Vandenbeuch, A., Stone, L. M., Margolskee, R. F., Chaudhari, N., and Kinnamon, S. C. (2008). Tonic activity of Galphagustducin regulates taste cell responsivity. FEBS Lett. 582, 3783-3787.

Clapp, T. R., Yang, R., Stoick, C. L., Kinnamon, S. C., and Kinnamon, J.C. (2004). Morphologic characterization of rat taste receptor cells that express components of the phospholipase $\mathrm{C}$ signaling pathway. J. Comp. Neurol. 468, 311-321.

Corvilain, B., Abramowicz, M., Fery, F., Schoutens, A., Verlinden, M., Balasse, E., and Horowitz, M. (1995). Effect of short-term starvation on gastric emptying in humans: relationship to oral glucose tolerance. Am. J. Physiol. 269, G512-G517.

Cummings, D. E., and Overduin, J. (2007). Gastrointestinal regulation of food intake. J. Clin. Invest. 117, 13-23.

Damak, S., Rong, M., Yasumatsu, K., Kokrashvili, Z., Perez, C. A., Shigemura, N., Yoshida, R., Mosinger, B. Jr., Glendinning, J. I., Ninomiya, Y., and Margolskee, R. F. (2006). Trpm5 null mice respond to bitter, sweet, and umami compounds. Chem. Senses 31 , 253-264.

Damak, S., Rong, M., Yasumatsu, K., Kokrashvili,Z., Varadarajan, V.,Zou, S., Jiang, P., Ninomiya, Y., and Margolskee, R. F. (2003). Detection of sweet and umami taste in the absence of taste receptor T1r3. Science 301, 850-853.

Deacon, C. F,,Pridal, L., Klarskov, L., Olesen, M., and Holst, J.J. (1996). Glucagon-like peptide 1 undergoes differential tissuespecific metabolism in the anesthetized pig. Am. J. Physiol. 271, E458-E464.

Deane, A. M., Nguyen, N. Q., Stevens, J. E., Fraser, R. J., Holloway, R. H., Besanko, L. K., Burgstad, C., Jones, K. L., Chapman, M. J., Rayner, C. K., and Horowitz, M. (2010). Endogenous glucagon-like peptide-1 slows gastric emptying in healthy subjects, attenuating postprandial glycemia. J. Clin. Endocrinol. Metab. 95, 215-221.
DeFazio, R. A., Dvoryanchikov, G., Maruyama, Y., Kim, J. W., Pereira, E., Roper, S.D., and Chaudhari, N. (2006) Separate populations of receptor cells and presynaptic cells in mouse taste buds. J. Neurosci. 26, 3971-3980.

Delay, E. R., Hernandez, N. P., Bromley, K., and Margolskee, R. F. (2006). Sucrose and monosodium glutamate taste thresholds and discrimination ability of T1R3 knockout mice. Chem. Senses 31, 351-357.

Diez-Sampedro, A., Hirayama, B. A., Osswald,C.,Gorboulev, V., Baumgarten, K., Volk, C., Wright, E. M., and Koepsell, H. (2003). A glucose sensor hiding in a family of transporters. Proc. Natl. Acad. Sci. U.S.A. 100, 11753-11758.

Drucker,D.J., and Asa, S. (1988). Glucagon gene expression in vertebrate brain. $J$. Biol. Chem. 263, 13475-13478.

Dyer, J., Daly, K., Salmon, K. S., Arora, D. K., Kokrashvili, Z., Margolskee, R. F., and Shirazi-Beechey, S. P. (2007) Intestinal glucose sensing and regulation of intestinal glucose absorption. Biochem. Soc. Trans. 35, 1191-1194.

Dyer, J., Salmon, K. S., Zibrik, L., and Shirazi-Beechey, S. P. (2005). Expression of sweet taste receptors of the T1R family in the intestinal tract and enteroendocrine cells. Biochem. Soc. Trans. 33, 302-305.

Dyer, J., Vayro, S., King, T. P., and ShiraziBeechey, S. P. (2003). Glucose sensing in the intestinal epithelium. Eur. J. Biochem. 270, 3377-3388.

Eissele, R., Goke, R., Willemer, S., Harthus, H. P., Vermeer, H., Arnold, R., and Goke, B. (1992). Glucagon-like peptide- 1 cells in the gastrointestinal tract and pancreas of rat, pig and man. Eur. J. Clin. Invest. 22, 283-291.

El-Ouaghlidi, A., Rehring, E., Holst, J. J., Schweizer, A., Foley, J., Holmes, D., and Nauck, M. A. (2007). The dipeptidyl peptidase 4 inhibitor vildagliptin does not accentuate glibenclamide-induced hypoglycemia but reduces glucoseinduced glucagon-like peptide 1 and gastric inhibitory polypeptide secretion. J. Clin. Endocrinol. Metab. 92, 4165-4171.

Finger, T. E., Danilova, V., Barrows, J., Bartel, D. L., Vigers, A. J., Stone, L., Hellekant, G., and Kinnamon, S. C. (2005). ATP signaling is crucial for communication from taste buds to gustatory nerves. Science 310 , 1495-1499.

Frank, G. K., Oberndorfer, T.A., Simmons, A. N., Paulus, M. P., Fudge, J. L., Yang, T. T., and Kaye, W. H. (2008). Sucrose activates human taste pathways differently from artificial sweetener. Neuroimage 39, 1559-1569.

Freeman, S. L., Bohan, D., Darcel, N., and Raybould, H. E. (2006). Luminal glucose sensing in the rat intestine has characteristics of a sodium-glucose cotransporter. Am. J. Physiol. 291, G439-G445.

Fujita, Y., Wideman, R. D., Speck, M., Asadi, A., King, D. S., Webber, T. D., Haneda, M., and Kieffer, T. J. (2009). Incretin release from gut is acutely enhanced by sugar but not by sweeteners in vivo. Am. J. Physiol. Endocrinol. Metab. 296, E473-E479.

Fushiki, T., Kojima, A., Imoto, T., Inoue, K., and Sugimoto, E. (1992). An extract of Gymnema sylvestre leaves and purified gymnemic acid inhibits glucose-stimulated gastric inhibitory peptide secretion in rats. J. Nutr. 122, 2367-2373.

Gebert, A., al-Samir, K., Werner, K., Fassbender, S., and Gebhard, A. (2000). The apical membrane of intestinal brush cells possesses a specialised, but speciesspecific,composition of glycoconjugateson-section and in vivo lectin labelling in rats, guinea-pigs and mice. Histochem Cell Biol. 113, 389-399.

Glatzle, J., Sternini, C., Robin, C., Zittel, T. T., Wong, H., Reeve, J. R., and Raybould, H. E. (2002). Expression of 5-HT3 receptors in the rat gastrointestinal tract. Gastroenterology $123,217-226$

Goke, R., Larsen, P. J., Mikkelsen, J. D., and Sheikh, S. P. (1995). Distribution of GLP-1 binding sites in the rat brain: evidence that exendin- 4 is a ligand of brain GLP-1 binding sites. Eur. J. Neurosci. 7, 2294-2300.

Gregersen, S., Jeppesen, P. B., Holst, J. J., and Hermansen, K. (2004). Antihyperglycemic effects of stevioside in type 2 diabetic subjects. Metab. Clin. Exp. 53, 73-76.

Gribble, F. M., Williams, L., Simpson, A. K., and Reimann, F. (2003). A novel glucose-sensing mechanism contributing to glucagon-like peptide-1 secretion from the GLUTag cell line. Diabetes 52, 1147-1154.

Grundy, D. (2006). Serotonin and sensory signalling from the gastrointestinal lumen. J. Physiol. (Lond.) 575, 1-2.

Grundy, D. (2008). 5-HT system in the gut: roles in the regulation of visceral sensitivity and motor functions. Eur. Rev. Med. Pharmacol. Sci. 12(Suppl. 1), 63-67.

Gwynne, R.M., and Bornstein, J.C. (2007). Local inhibitory reflexes excited by mucosal application of nutrient amino acids in guinea pig jejunum. Am. J. Physiol. 292, G1660-G1670.

Höfer, D., and Drenckhahn, D. (1996). Cytoskeletal markers allowing discrimination between brush cells and other epithelial cells of the gut including enteroendocrine cells. Histochem. Cell Biol. 105, 405-412.

Höfer, D., and Drenckhahn, D. (1998). Identification of the taste cell 
G-protein, alpha-gustducin, in brush cells of the rat pancreatic duct system. Histochem. Cell Biol. 110, 303-309.

Höfer, D., Puschel, B., and Drenckhahn, D. (1996). Taste receptor-like cells in the rat gut identified by expression of alpha-gustducin. Proc. Natl. Acad. Sci. U.S.A. 93, 6631-6634.

Holmes, G.M., Browning, K. N., Tong, M., Qualls-Creekmore, E., and Travagli, R. A. (2009). Vagally mediated effects of glucagon-like peptide 1 : in vitro and in vivo gastric actions. J. Physiol. (Lond.) 587, 4749-4759.

Holst, J. J. (2007). The physiology of glucagon-like peptide 1. Physiol. Rev. 87, 1409-1439.

Holst, J. J., and Gromada, J. (2004). Role of incretin hormones in the regulation of insulin secretion in diabetic and nondiabetic humans. Am. J. Physiol. 287, E199-E206.

Hoon, M. A., Adler, E., Lindemeier, J., Battey, J. F., Ryba, N. J., and Zuker, C. S. (1999). Putative mammalian taste receptors: a class of taste-specific GPCRs with distinct topographic selectivity. Cell 96, 541-551.

Horowitz, M., Cunningham, K. M., Wishart, J. M., Jones, K. L., and Read, N. W. (1996). The effect of short-term dietary supplementation with glucose on gastric emptying of glucose and fructose and oral glucose tolerance in normal subjects. Diabetologia 39, 481-486.

Horowitz, M., and Dent, J. (1991). Disordered gastric emptying: mechanical basis, assessment and treatment. Baillieres Clin. Gastroenterol. 5, 371-407.

Horowitz, M., Maddox, A. F., Wishart, J. M., Harding, P. E., Chatterton, B. E., and Shearman, D. J. C. (1991). Relationships between oesophageal transit and solid and liquid gastric emptying in diabetes mellitus. Eur. J. Nucl. Med. 18, 229-234.

Horowitz, M., and Nauck, M.A. (2006). To be or not to be - an incretin or enterogastrone? Gut 55, 148-150.

Horowitz, M., O'Donovan, D., Jones, K. L., Feinle, C., Rayner, C. K., and Samsom, M. (2002). Gastric emptying in diabetes: clinical significance and treatment. Diabet. Med. 19, 177-194.

Huang, Y. A., Dando, R., and Roper, S. D. (2009). Autocrine and paracrine roles for ATP and serotonin in mouse taste buds. J. Neurosci. 29, 13909-13918.

Huang, Y. A., Maruyama, Y., Stimac, R., and Roper, S. D. (2008). Presynaptic (Type III) cells in mouse taste buds sense sour (acid) taste. J. Physiol. (Lond.) 586, 2903-2912.

Imeryuz, N., Yegen, B. C., Bozkurt, A., Coskun, T., Villanueva-Penacarrillo, M. L., and Ulusoy, N. B. (1997). Glucagon-like peptide-1 inhibits gastric emptying via vagal afferent- mediated central mechanisms. Am. J. Physiol. 273, G920-G927.

Jang, H. J., Kokrashvili, Z., Theodorakis, M. J., Carlson, O. D., Kim, B. J., Zhou, J., Kim, H. H., Xu, X., Chan, S. L., Juhaszova, M., Bernier, M., Mosinger, B., Margolskee, R. F., and Egan, J. M. (2007). Gut-expressed gustducin and taste receptors regulate secretion of glucagon-like peptide-1. Proc. Natl. Acad. Sci. U.S.A. 104, 15069-15074.

Kakei, M., Yada, T., Nakagawa, A., and Nakabayashi, H. (2002). Glucagonlike peptide-1 evokes action potentials and increases cytosolic $\mathrm{Ca} 2+$ in rat nodose ganglion neurons. Auton. Neurosci. 102, 39-44.

Kataoka, S., Toyono, T., Seta, Y., Ogura, T., and Toyoshima, K. (2004). Expression of P2Y1 receptors in rat taste buds. Histochem. Cell Biol. 121, 419-426.

Kataoka, S., Yang, R., Ishimaru, Y., Matsunami, H., Sevigny, J., Kinnamon, J. C., and Finger, T. E. (2008). The candidate sour taste receptor, $\mathrm{PKD} 2 \mathrm{~L} 1$, is expressed by type III taste cells in the mouse. Chem. Senses 33, 243-254.

Kidd, M., Modlin, I. M., Gustafsson, B. I., Drozdov, I., Hauso, O., and Pfragner, R. (2008). Luminal regulation of normal and neoplastic human EC cell serotonin release is mediated by bile salts, amines, tastants, and olfactants. Am. J. Physiol. 295, G260-G272.

Kim, M., Cooke, H. J., Javed, N. H., Carey, H.V., Christofi, F., and Raybould, H.E. (2001). D-glucose releases 5-hydroxytryptamine from human BON cells as a model of enterochromaffin cells. Gastroenterology 121, 1400-1406.

Kim, M. R., Kusakabe, Y., Miura, H., Shindo, Y., Ninomiya, Y., and Hino, A. (2003). Regional expression patterns of taste receptors and gustducin in the mouse tongue. Biochem. Biophys. Res. Commun. 312, 500-506.

Kim, S. J., Nian, C., and McIntosh, C. H. (2007).Activation of lipoprotein lipase by glucose-dependent insulinotropic polypeptide in adipocytes. A role for a protein kinase $\mathrm{B}, \mathrm{LKB} 1$, and AMPactivated protein kinase cascade. $J$. Biol. Chem. 282, 8557-8567.

Kim, Y. V., Bobkov, Y. V., and Kolesnikov, S. S. (2000). Adenosine triphosphate mobilizes cytosolic calcium and modulates ionic currents in mouse taste receptor cells. Neurosci. Lett. 290, 165-168.

Kokrashvili,Z., Rodriguez, D., Yevshayeva, V., Zhou, H., Margolskee, R. F., and Mosinger, B. (2009). Release of endogenous opioids from duodenal enteroendocrine cells requires Trpm5. Gastroenterology 137, 598-606.

Kugler, P., Höfer, D., Mayer, B., and Drenckhahn, D. (1994). Nitric oxide synthase and NADP-linked glucose- 6-phosphate dehydrogenase are colocalized in brush cells of rat stomach and pancreas. J. Histochem. Cytochem. 42, 1317-1321.

Kumar, K. G., Byerley, L. O., Volaufova, J., Drucker, D. J., Churchill, G. A., Li, R. York, B., Zuberi, A., and Richards, B. K. (2008). Genetic variation in Glp1r expression influences the rate of gastric emptying in mice. Am. J. Physiol. 294, R362-R371.

Lavin, J. H., Wittert, G., Sun, W. M., Horowitz, M., Morley, J. E., and Read, N. W. (1996). Appetite regulation by carbohydrate: role of blood glucose and gastrointestinal hormones. Am J. Physiol. 271, E209-E214.

Lawton, D. M., Furness, D. N., Lindemann, B., and Hackney, C. M. (2000). Localization of the glutamate-aspartate transporter, GLAST, in rat taste buds. Eur. J. Neurosci. 12, 3163-3171.

Li, X., Staszewski, L., Xu, H., Durick, K., Zoller, M., and Adler, E. (2002). Human receptors for sweet and umami taste. Proc. Natl. Acad. Sci. U.S.A. 99, 4692-4696.

Liddle, R. A., Goldfine, I. D., Rosen, M. S., Taplitz, R. A., and Williams, J. A. (1985). Cholecystokinin bioactivity in human plasma. Molecular forms, responses to feeding, and relationship to gallbladder contraction. J. Clin Invest. 75, 1144-1152.

Lin, H. C., Doty, J. E., Reedy, T. J., and Meyer, J. H. (1989). Inhibition of gastric emptying by glucose depends on length of intestine exposed to nutrient. Am. J. Physiol. 256, G404-G411.

Lindemann, B. (2001). Receptors and transduction in taste. Nature 413 219-225.

Linden, D. R.,Sha, L., Mazzone, A.,Stoltz, G. J., Bernard, C. E., Furne, J. K., Levitt, M. D., Farrugia, G., and Szurszewski, J. H. (2008). Production of the gaseous signal molecule hydrogen sulfide in mouse tissues. J. Neurochem. 106, 1577-1585.

Little, T. J., Doran, S., Meyer, J. H., Smout, A. J., O’Donovan, D. G., Wu, K. L., Jones, K. L., Wishart, J., Rayner, C. K., Horowitz, M., and Feinle-Bisset, C. (2006). The release of GLP-1 and ghrelin, but not GIP and CCK, by glucose is dependent upon the length of small intestine exposed. Am. J. Physiol. 291, E647-E655.

Little, T. J., Gupta, N., Case, R. M. Thompson, D. G., and McLaughlin, J. T. (2009). Sweetness and bitterness taste of meals per se does not mediate gastric emptying in humans. Am. J. Physiol. 297, R632-R639.

Ma, J., Bellon, M., Wishart, J. M., Young, R. L., Blackshaw, L. A., Jones, K. L., Horowitz, M., and Rayner, C. K. (2009). Effect of the artificial sweetener, sucralose, on gastric empty- ing and incretin hormone release in healthy subjects. Am. J. Physiol. 296, G735-G739.

Ma, J., Chang, J., Checklin, H. L., Young, R. L., Jones, K. L., Horowitz, M., and Rayner, C. K. (2010). Effect of the artificial sweetener, sucralose, on small intestinal glucose absorption in healthy human subjects. Br. J. Nutr. 104, 803-806.

Mace, O. J., Affleck, J., Patel, N., and Kellett, G. L. (2007). Sweet taste receptors in rat small intestine stimulate glucose absorption through apical GLUT2. J. Physiol. (Lond.) 582, 379-392.

Mace, O. J., Lister, N., Morgan, E. L., West, E. J., Affleck, J., Helliwell, P. A., Bronk, J. R., Kellett, G. L., Meredith, D., Boyd, C. A., Myrtani, P., Bailey, P. D., Pettecrew, R., and Foley, D. (2008). An energy supply network of nutrient absorption coordinated by calcium and T1R taste receptors in rat small intestine. J. Physiol. (Lond.) 587, 195-210.

Margolskee, R. F., Dyer, J., Kokrashvili, Z., Salmon, K. S., Ilegems, E., Daly, K., Maillet, E. L., Ninomiya, Y., Mosinger, B., and Shirazi-Beechey, S. P. (2007). T1R 3 and gustducin in gut sense sugars to regulate expression of $\mathrm{Na}$-glucose cotransporter 1. Proc. Natl. Acad. Sci. U.S.A. 104, 15075-15080.

Martin, B., Dotson, C. D., Shin, Y. K., Ji, S., Drucker, D. J., Maudsley, S., and Munger, S. D. (2009). Modulation of taste sensitivity by GLP-1 signaling in taste buds. Ann. N. Y. Acad. Sci. 1170, 98-101.

McFadden, D. W., Jaffe, B. M., Ferrara, A., and Zinner, M. J. (1984). Jejunal absorptive response to a test meal and its modification by cholinergic and calcium-channel blockade in the awake dog. Surg. Forum 35, 174-176.

Meier, J. J., Goetze, O., Anstipp, J., Hagemann, D., Holst, J. J., Schmidt, W. E., Gallwitz, B., and Nauck, M. A. (2004). Gastric inhibitory polypeptide does not inhibit gastric emptying in humans. Am. J. Physiol. 286, E621-E625.

Merchenthaler, I., Lane, M., and Shughrue, P. (1999). Distribution of pre-pro-glucagon and glucagon-like peptide-1 receptor messenger RNAs in the rat central nervous system. $J$. Comp. Neurol. 403, 261-280.

Miller, S. M., Farrugia, G., Schmalz, P. F., Ermilov, L. G., Maines, M. D., and Szurszewski, J. H. (1998). Heme oxygenase 2 is present in interstitial cell networks of the mouse small intestine. Gastroenterology 114, 239-244.

Moran, A. W., Al-Rammahi, M. A., Arora, D. K., Batchelor, D. J., Coulter, E. A., Daly, K., Ionescu, C., Bravo, D., and Shirazi-Beechey, S. P. (2010a). Expression of $\mathrm{Na} /$ glucose cotransporter 1 (SGLT1) is enhanced 
by supplementation of the diet of weaning piglets with artificial sweeteners. Br. J. Nutr. 104, 637-646.

Moran,A.W.,Al-Rammahi, M.A., Arora, D. K., Batchelor, D. J., Coulter, E. A., Ionescu, C., Bravo, D., and ShiraziBeechey, S. P. (2010b). Expression of $\mathrm{Na}+$ /glucose co-transporter 1 (SGLT1) in the intestine of piglets weaned to different concentrations of dietary carbohydrate. Br. J. Nutr. 104, 647-655.

Morini, G., Bassoli, A., and Temussi, P. A. (2005). From small sweeteners to sweet proteins: anatomy of the binding sites of the human T1R2_T1R3 receptor. J. Med. Chem. 48, 5520-5529.

Moriya, R., Shirakura, T., Ito, J., Mashiko, S., and Seo, T. (2009). Activation of sodium-glucose cotransporter 1 ameliorates hyperglycemia by mediating incretin secretion in mice. Am. J. Physiol. 297, E1358-E1365.

Morroni, M., Cangiotti, A. M., and Cinti, S. (2007). Brush cells in the human duodenojejunal junction: an ultrastructural study. J. Anat. 211, 125-131.

Murata, Y., Yasuo, T., Yoshida, R., Obata, K., Yanagawa, Y., Margolskee, R. F., and Ninomiya, Y. (2010). Action potential-enhanced ATP release from taste cells through hemichannels. J. Neurophysiol. 104, 896-901.

Nagahama, S., and Kurihara, K. (1985). Norepinephrine as a possible transmitter involved in synaptic transmission in frog taste organs and $\mathrm{Ca}$ dependence of its release. J. Gen. Physiol. 85, 431-442.

Nagai, T., Delay, R. J., Welton, J., and Roper, S.D. (1998). Uptake and release of neurotransmitter candidates, $[3 \mathrm{H}]$ serotonin, $[3 \mathrm{H}]$ glutamate, and $[3 \mathrm{H}]$ gamma-aminobutyric acid, in taste buds of the mudpuppy, Necturus maculosus. J. Comp. Neurol. 392, 199-208.

Nagell, C. F., Wettergren, A., Ørskov, C., and Holst, J. J. (2006). Inhibitory effect of GLP-1 on gastric motility persists after vagal deafferentation in pigs. Scand. J. Gastroenterol. 41, 667-672.

Nakade, Y., Tsukamoto, K., Pappas, T. N., and Takahashi, T. (2006). Central glucagon like peptide-1 delays solid gastric emptying via central CRF and peripheral sympathetic pathway in rats. Brain Res. 1111, 117-121.

Nakagawa, A., Satake, H., Nakabayashi,H., Nishizawa, M., Furuya, K., Nakano, S., Kigoshi, T., Nakayama, K., and Uchida, K. (2004). Receptor gene expression of glucagon-like peptide-1, but not glucose-dependent insulinotropic polypeptide, in rat nodose ganglion cells. Auton. Neurosci. 110, 36-43.

Nakagawa, Y., Nagasawa, M., Yamada, S., Hara, A., Mogami, H., Nikolaev, V. O., Lohse, M.J., Shigemura, N., Ninomiya,
Y., and Kojima, I. (2009). Sweet taste receptor expressed in pancreatic $\beta$-cells activates the calcium and cyclic AMP signaling systems and stimulates insulin secretion. PLoS ONE 4, e5106. doi: 10.1371/journal.pone.0005106

Nelson, G., Chandrashekar, J., Hoon, M. A., Feng, L., Zhao, G., Ryba, N. J., and Zuker, C. S. (2002). An amino-acid taste receptor. Nature 416, 199-202.

Nelson, G., Hoon, M. A., Chandrashekar, J., Zhang, Y., Ryba, N. J., and Zuker, C. S. (2001). Mammalian sweet taste receptors. Cell 106, 381-390.

Netzer, P., Gaia, C., Lourens, S. T., Reber, P., Wildi, S., Noelpp, U., Ritter, E. P., Ledermann, H., Luscher, D., Varga, L., Kinser, J. A., Buchler, M. W., and Scheurer, U. (2002). Does intravenous ondansetron affect gastric emptying of a solid meal, gastric electrical activity or blood hormone levels in healthy volunteers? Aliment. Pharmacol. Ther. 16, 119-127.

Nie, Y., Vigues, S., Hobbs, J. R., Conn, G. L., and Munger, S. D. (2005). Distinct contributions of T1R2 and T1R3 taste receptor subunits to the detection of sweet stimuli. Curr. Biol. 15, 1948-1952.

Nielsen, L. B., Ploug, K. B., Swift, P., Orskov, C., Jansen-Olesen, I., Chiarelli, F., Holst, J. J., Hougaard, P., Porksen, S., Holl, R., de Beaufort, C., Gammeltoft, S., Rorsman, P., Mortensen, H. B., and Hansen, L. (2007). Co-localisation of the Kir6.2/SUR1 channel complex with glucagon-like peptide- 1 and glucose-dependent insulinotrophic polypeptide expression in human ileal cells and implications for glycaemic control in new onset type 1 diabetes. Eur. J. Endocrinol. 156, 663-671.

Nishizawa, M., Nakabayashi, H., Uchida, K., Nakagawa, A., and Niijima, A. (1996). The hepatic vagal nerve is receptive to incretin hormone glucagon-like peptide-1, but not to glucose-dependent insulinotropic polypeptide, in the portal vein. $J$. Auton. Nerv. Syst. 61, 149-154.

Ohkuri, T., Yasumatsu, K., Horio, N., Jyotaki, M., Margolskee, R. F., and Ninomiya, Y. (2009). Multiple sweet receptors and transduction pathways revealed in knockout mice by temperature dependence and gurmarin sensitivity. Am. J. Physiol. 296, R960-R971.

Ozeck, M., Brust, P., Xu, H., and Servant, G. (2004). Receptors for bitter, sweet and umami taste couple to inhibitory G protein signaling pathways. Eur. J. Pharmacol. 489, 139-149.

Parker, H. E., Habib, A. M., Rogers, G. J., Gribble, F. M., and Reimann, F. (2009). Nutrient-dependent secretion of glucose-dependent insulinotropic polypeptide from primary murine K cells. Diabetologia 52, 289-298.
Perez, C. A., Huang, L., Rong, M., Kozak, J. A., Preuss, A. K., Zhang, H., Max, M., and Margolskee, R. F. (2002). A transient receptor potential channel expressed in taste receptor cells. Nat. Neurosci. 5, 1169-1176.

Pilichiewicz, A. N., Chaikomin, R., Brennan, I. M., Wishart, J. M. Rayner, C. K., Jones, K. L., Smout, A. J., Horowitz, M., and Feinle-Bisset, C. (2007). Load-dependent effects of duodenal glucose on glycemia, gastrointestinal hormones, antropyloroduodenal motility, and energy intake in healthy men. Am. J. Physiol. 293, E743-E753.

Raybould, H. E. (1991). Capsaicinsensitive vagal afferents and CCK in inhibition of gastric motor function induced by intestinal nutrients. Peptides 12, 1279-1283.

Raybould, H. E. (1998). Does your gut taste? Sensory transduction in the gastrointestinal tract. News Physiol. Sci. 13, 275-280.

Raybould, H. E. (2010). Gut chemosensing: interactions between gut endocrine cells and visceral afferents. Auton Neurosci. 153, 41-46.

Raybould, H. E., Glatzle, J., Robin, C., Meyer, J. H., Phan, T., Wong, H., and Sternini, C. (2003). Expression of 5-HT3 receptors by extrinsic duodenal afferents contribute to intestinal inhibition of gastric emptying. Am. J. Physiol. 284, G367-G372.

Raybould, H. E., and Holzer, H. (1992) Dual capsaicin-sensitive afferent pathways mediate inhibition of gastric emptying in rat induced by intestinal carbohydrate. Neurosci. Lett. 141 , 236-238.

Rayner, C. K., Schwartz, M. P., van Dam, P. S., Renooij, W., de Smet, M., Horowitz, M., Smout, A. J., and Samsom, M. (2002). Small intestinal glucose absorption and duodenal motility in type 1 diabetes mellitus. Am. J. Gastroenterol. 97, 3123-3130.

Rehfeld, J. F. (1978). Immunochemical studies on cholecystokinin. II. Distribution and molecular heterogeneity in the central nervous system and small intestine of man and hog. J. Biol. Chem. 253, 4022-4030.

Reid, L., Meyrick, B., Antony, V. B., Chang, L. Y., Crapo, J. D., and Reynolds, H. Y. (2005). The mysterious pulmonary brush cell: a cell in search of a function. Am. J. Respir. Crit. Care Med. 172, 136-139.

Reimann, F. (2010). Molecular mechanisms underlying nutrient detection by incretin-secreting cells. Int. Dairy J. 20, 236-242.

Reimann, F., and Gribble, F. M. (2002). Glucose-sensing in glucagon-like peptide-1-secreting cells. Diabetes 51, 2757-2763.
Reimann, F., Habib, A. M., Tolhurst, G. Parker, H.E., Rogers, G. J., and Gribble, F.M. (2008). Glucose sensing in L cells: a primary cell study. Cell Metab. 8 , 532-539.

Reimann, F., Maziarz, M., Flock, G., Habib, A. M., Drucker, D. J., and Gribble, F. M. (2005). Characterization and functional role of voltage gated cation conductances in the glucagon-like peptide-1 secreting GLUTag cell line. J. Physiol. (Lond.) 563, 161-175.

Ren, X., Zhou, L., Terwilliger, R., Newton, S. S., and de Araujo, I. E. (2009). Sweet taste signaling functions as a hypothalamic glucose sensor. Front. Integr. Neurosci. 3:12. doi: 10.3389/ neuro.07.012.2009

Rindi, G., Leiter, A. B., Kopin, A. S., Bordi, C., and Solcia, E. (2004). The "normal" endocrine cell of the gut: changing concepts and new evidences. Ann. N. Y. Acad. Sci. 1014, 1-12.

Ritzel, U., Fromme, A., Ottleben, M., Leonhardt, U., and Ramadori, G. (1997). Release of glucagon-like peptide-1 (GLP-1) by carbohydrates in the perfused rat ileum. Acta Diabetol. 34, 18-21.

Romanov, R. A., Rogachevskaja, O. A., Bystrova, M. F., Jiang, P., Margolskee, R. F., and Kolesnikov, S. S. (2007). Afferent neurotransmission mediated by hemichannels in mammalian taste cells. EMBO J. 26, 657-667.

Roper, S. D. (2007). Signal transduction and information processing in mammalian taste buds. Pflugers Arch. 454, 759-776.

Rorsman, P. (1997). The pancreatic betacell as a fuel sensor: an electrophysiologist's viewpoint. Diabetologia 40, 487-495.

Roze, C., Couturier, D., Chariot, J., and Debray, C. (1977). Inhibition of gastric electrical and mechanical activity by intraduodenal agents in pigs and the effects of vagotomy. Digestion 15, 526-539.

Rozengurt, E., and Sternini, C. (2007). Taste receptor signaling in the mammalian gut. Curr. Opin. Pharmacol. 7 , 557-562.

Rozengurt, N., Wu, S. V., Chen, M. C., Huang, C., Sternini, C., and Rozengurt, E. (2006). Colocalization of the alphasubunit of gustducin with PYY and GLP-1 in L cells of human colon. Am. J. Physiol. 291, G792-G802.

Ruttimann, E. B., Arnold, M., Hillebrand, J. J., Geary, N., and Langhans, W. (2009). Intrameal hepatic portal and intraperitoneal infusions of glucagon-like peptide-1 reduce spontaneous meal size in the rat via different mechanisms. Endocrinology 150, 1174-1181.

Savastano, D. M., Carelle, M., and Covasa, M. (2005). Serotonin-type 3 recep- 
tors mediate intestinal Polycose- and glucose-induced suppression of intake. Am. J. Physiol. 288, R1499-R1508.

Schiffman, S. S., Booth, B. J., Carr, B. T., Losee, M. L., Sattely-Miller, E. A., and Graham, B. G. (1995). Investigation of synergism in binary mixtures of sweeteners. Brain Res. Bull. 38, 105-120.

Schirra, J., and Göke, B. (2005). The physiological role of GLP-1 in human: incretin, ileal brake or more? Regul. Pept. 128, 109-115.

Schirra, J., Nicolaus, M., Woerle, H. J., Struckmeier, C., Katschinski, M., and Goke, B. (2009). GLP-1 regulates gastroduodenal motility involving cholinergic pathways. Neurogastroenterol. Motil. 21, 609-618.

Schwartz, G. J., Berkow, G., McHugh, P. R., and Moran, T. H. (1993). Gastric branch vagotomy blocks nutrient and cholecystokinin-induced suppression of gastric emptying. Am. J. Physiol. 264, R630-R637.

Shen, T., Kaya, N., Zhao, F. L., Lu, S. G., Cao, Y., and Herness, S. (2005). Co-expression patterns of the neuropeptides vasoactive intestinal peptide and cholecystokinin with the transduction molecules alphagustducin and T1R2 in rat taste receptor cells. Neuroscience 130, 229-238.

Shigemura, N., Nakao, K., Yasuo, T., Murata, Y., Yasumatsu, K., Nakashima, A., Katsukawa, H., Sako, N., and Ninomiya, Y. (2008). Gurmarin sensitivity of sweet taste responses is associated with co-expression patterns of T1r2, T1r3, and gustducin. Biochem. Biophys. Res. Commun. 367, 356-363.

Shirazi-Beechey, S. P., Hirayama, B. A., Wang, Y., Scott, D., Smith, M. W., and Wright, E. M. (1991). Ontogenic development of lamb intestinal sodiumglucose co-transporter is regulated by diet. J. Physiol. (Lond.) 437, 699-708.

Singh, S. K., Bartoo, A. C., Krishnan, S., Boylan, M. O., Schwartz, J. H., and Michael Wolfe, M. (2008). Glucosedependent insulinotropic polypeptide (GIP) stimulates transepithelial glucose transport. Obesity (Silver Spring) $16,2412-2416$

Stacher, G., Bergmann, H., GranserVacariu, G. V., Wiesnagrotzki, S., Wenzelabatzi, T. A., Gaupmann, G., Kugi, A., Steinringer, H., Schneider, C., and Hobart, J. (1991). Lack of systematic effects of the 5-hydroxytryptamine 3 receptor antagonist ICS 205-930 on gastric emptying and antral motor activity in patients with primary anorexia nervosa. Br. J. Clin. Pharmacol. 32, 685-689.

Stacher, G., Bergmann, H., Schneider, C., Steiner-Mittelbach, G., Gaupmann, G., Steinringer, H., Abatzi, T. A., and Stacher-Janotta, G. (1990). Effects of the 5-HT3 receptor antagonist ICS 205-930 on fat-delayed gastric emptying and antral motor activity. $\mathrm{Br}$. J. Clin. Pharmacol. 30, 41-48.

Stearns, A. T., Balakrishnan, A., Rhoads, D. B., and Tavakkolizadeh, A. (2010). Rapid upregulation of sodiumglucose transporter SGLT1 in response to intestinal sweet taste stimulation. Ann. Surg. 251, 865-871.

Stearns, A. T., Balakrishnan, A., Rounds, J., Rhoads, D. B., Ashley, S. W., and Tavakkolizadeh, A. (2008). Capsaicin-sensitive vagal afferents modulate posttranscriptional regulation of the rat $\mathrm{Na}+$ /glucose cotransporter SGLT1. Am. J. Physiol. 294, G1078-G1083.

Stone, L. M., Tan, S. S., Tam, P. P., and Finger, T. E. (2002). Analysis of cell lineage relationships in taste buds. $J$. Neurosci. 22, 4522-4529.

Sutherland, K., Brierley, S. M., Horowitz, M., Rayner, C. K., Blackshaw, L. A., and Young, R. L. (2007a). Sweet taste transduction molecules are expressed in the upper gastrointestinal tract in humans. Gastroenterology 132(Suppl. 2), T1939.

Sutherland, K., Young, R. L., Cooper, N. J., Horowitz, M., and Blackshaw, L. A. (2007b). Phenotypic characterization of taste cells of the mouse small intestine. Am. J. Physiol. 292, G1420-G1428.

Sutherland, K., Brierley, S. M., Horowitz, M., Rayner, C. K., Blackshaw, L.A., and Young, R. L. (2008). Altered duodenal sweet taste receptor expression in diabetic hyperglycemia. Gastroenterology 134(Suppl. 2), 311.

Sykes, S., Morgan, L. M., English, J., and Marks, V. (1980). Evidence for preferential stimulation of gastric inhibitory polypeptide secretion in the rat by actively transported carbohydrates and their analogues. J. Endocrinol. 85, 201-207.

Theodorakis, M. J., Carlson, O., Michopoulos, S., Doyle, M. E., Juhaszova, M., Petraki, K., and Egan, J. M. (2006). Human duodenal enteroendocrine cells: source of both incretin peptides, GLP-1 and GIP. Am. J. Physiol. 290, E550-E559.

Tolhurst, G., Reimann, F., and Gribble, F. M. (2009). Nutritional regulation of glucagon-like peptide-1 secretion. $J$. Physiol. (Lond.) 587, 27-32.

Turk, E., Zabel, B., Mundlos, S., Dyer, J., and Wright, E. M. (1991). Glucose/ galactose malabsorption caused by a defect in the $\mathrm{Na}+$ /glucose cotransporter. Nature 350, 354-356.

Vahl, T. P., Tauchi, M., Durler, T. S., Elfers, E. E., Fernandes, T. M., Bitner, R. D., Ellis, K. S., Woods, S. C., Seeley, R. J., Herman, J. P., and D’Alessio, D.
A. (2007). Glucagon-like peptide-1 (GLP-1) receptors expressed on nerve terminals in the portal vein mediate the effects of endogenous GLP-1 on glucose tolerance in rats. Endocrinology 148, 4965-4973.

Vandenbeuch, A., Clapp, T. R., and Kinnamon, S. C. (2008). Amiloridesensitive channels in type I fungiform taste cells in mouse. BMC Neurosci. 9 , 1. doi: 10.1186/1471-2202-9-1

Wachters-Hagedoorn, R.E., Priebe, M. G. Heimweg, J. A., Heiner, A. M., Englyst, K.N., Holst, J.J., Stellaard, F., and Vonk, R. J. (2006). The rate of intestinal glucose absorption is correlated with plasma glucose-dependent insulinotropic polypeptide concentrations in healthy men. J. Nutr. 136, 1511-1516. Wilkinson, A. R., and Johnston, D. (1973). Effect of truncal, selective and highly selective vagotomy on gastric emptying and intestinal transit of a food-barium meal in man. Ann. Surg. 178, 190-193.

Wong, G. T., Gannon, K. S., and Margolskee, R. F. (1996). Transduction of bitter and sweet taste by gustducin. Nature 381, 796-800.

Wu, S. V., Rozengurt, N., Yang, M., Young, S.H., Sinnett-Smith, J., and Rozengurt, E. (2002). Expression of bitter taste receptors of the T2R family in the gastrointestinal tract and enteroendocrine STC-1 cells. Proc. Natl. Acad. Sci. U.S.A. 99, 2392-2397.

Wu, X. Y., Zhu, J. X., Gao, J., Owyang, C., and Li, Y. (2005). Neurochemical phenotype of vagal afferent neurons activated to express C-FOS in response to luminal stimulation in the rat Neuroscience 130, 757-767.

Xu, H., Staszewski, L., Tang, H., Adler, E., Zoller, M., and Li, X. (2004). Different functional roles of T1R subunits in the heteromeric taste receptors. Proc. Natl. Acad. Sci. U.S.A. 101, 14258-14263.

Yang, R., Tabata, S., Crowley, H. H., Margolskee, R. F., and Kinnamon, J. C. (2000). Ultrastructural localization of gustducin immunoreactivity in microvilli of type II taste cells in the rat. J. Comp. Neurol.425, 139-151.

Yarmolinsky, D. A., Zuker, C. S., and Ryba, N. J. P. (2009). Common sense about taste: from mammals to insects. Cell 139, 234-244.

Yip, R. G., Boylan, M. O., Kieffer, T. J., and Wolfe, M. M. (1998). Functional GIP receptors are present on adipocytes. Endocrinology 139, 4004-4007.

Yoshida, R., Miyauchi, A., Yasuo, T. Jyotaki, M., Murata, Y., Yasumatsu, K., Shigemura, N., Yanagawa, Y., Obata, K., Ueno, H., Margolskee, R. F., and Ninomiya, Y. (2009). Discrimination of taste qualities among mouse fungiform taste bud cells. J. Physiol. (Lond.) $587,4425-4439$.
Young, R. L., Sutherland, K., Pezos, N., Brierley, S. M., Horowitz, M., Rayner, C. K., and Blackshaw, L. A. (2009). Expression of taste molecules in the upper gastrointestinal tract in humans with and without type 2 diabetes. Gut $58,337-346$.

Young, R. L., Sutherland, K., Pezos, N. Brierley, S. M., Ma, J., Rayner, C. K., Horowitz, M. and Blackshaw, L. A. (2010). Control of intestinal sweet taste receptor expression is impaired in type 2 diabetes. Neurogastroenterol. Motil. 22 (Suppl.) 1, 31.

Zhang, F., Klebansky, B., Fine, R. M., Liu, H., Xu, H., Servant, G., Zoller, M., Tachdjian, C., and Li, X. (2010). Molecular mechanism of the sweet taste enhancers. Proc. Natl. Acad. Sci. U.S.A. 107, 4752-4757.

Zhao, F. L., Shen, T., Kaya, N., Lu, S. G., Cao, Y., and Herness, S. (2005). Expression, physiological action, and coexpression patterns of neuropeptide $\mathrm{Y}$ in rat taste-bud cells. Proc. Natl. Acad. Sci. U.S.A. 102, 11100-11105.

Zhao, G. Q., Zhang, Y., Hoon, M. A., Chandrashekar, J., Erlenbach, I., Ryba, N. J., and Zuker, C. S. (2003). The receptors for mammalian sweet and umami taste. Cell 115, 255-266.

Zhu, J., Zhu, X., Owyang, C., and Li, Y. (2001). Intestinal serotonin acts as a paracrine substance to mediate vagal signal transmission evoked by luminal factors in the rat. J. Physiol. (Lond.) 530, 431-442.

Zittel, T. T., Rothenhofer, I., Meyer, J. H., and Raybould, H. E. (1994). Small intestinal capsaicin-sensitive afferents mediate feedback inhibition of gastric emptying in rats. Am. J. Physiol. 267 G1142-G1145.

Conflict of Interest Statement: The author declares that the research was conducted in the absence of any commercial or financial relationships that could be construed as a potential conflict of interest.

Received: 14 August 2010; paper pending published: 28 September 2010; accepted: 10 February 2011; published online: 09 March 2011.

Citation: Young RL (2011) Sensing via intestinal sweet taste pathways. Front. Neurosci. 5:23. doi: 10.3389/fnins.2011.00023

This article was submitted to Frontiers in Autonomic Neuroscience, a specialty of Frontiers in Neuroscience.

Copyright (๑) 2011 Young. This is an openaccess article subject to a non-exclusive license between the authors and Frontiers Media $S A$, which permits use, distribution and reproduction in other forums, provided the original authors and source are credited and other Frontiers conditions are complied with. 